\title{
Hedge effectiveness of put replication, gold, and oil on ASEAN-5 equities
}

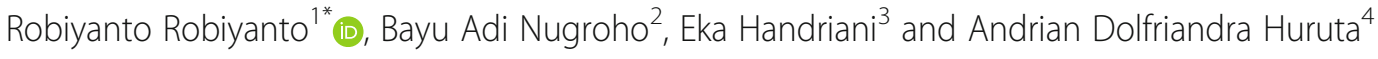

\author{
* Correspondence: robiyanto. \\ robiyanto@uksw.edu \\ ${ }^{1}$ Faculty of Economics and Business, \\ Satya Wacana Christian University, \\ J. Diponegoro 52-60, Salatiga \\ 50711, Indonesia \\ Full list of author information is \\ available at the end of the article
}

\begin{abstract}
The previous studies have shown that capital market integration has increased in the ASEAN-5, implying that investors making investment diversification across ASEAN capital markets could only earn limited diversification advantages. To diversify their portfolios, equity investors must find other assets. The main focus of this research is to analyze the effectiveness of put replication, gold, and oil on hedge equities in the ASEAN-5 (Indonesia, Malaysia, Singapore, Thailand, and the Philippines). Protective put strategy, DCC-GARCH, and Markowitz optimization are used to measure hedge effectiveness, risk-adjusted-performance such as Sharpe ratio, drawdown, and Omega ratio. The result reveals that gold is a cheaper hedge than oil and oil-hedged strategy is more expensive in ASEAN-5 compared to oil exporting nations. Also, investors with big exposure to the oil-related portfolio should diversify to Philippine equity. From hedging effectiveness and risk-adjusted-performance perspectives, oil is less attractive than money market instruments and gold. This study also implies that risk-averse investors should prefer to put replication or guaranteed financial products compared to commodities-hedged strategy.
\end{abstract}

Keywords: DCC-GARCH, Gold, Oil, Minimum variance, Portfolio insurance JEL classification: G11, G13, Q02, C22

\section{SpringerOpen}

\section{Introduction}

There has been an ongoing discussion about the usefulness of oil and gold for hedging the equities market. The topic has been vastly researched in developed nations such as United Kingdom, United States, and China (Baur and Tran 2012; Ciner et al. 2013; Creti et al. 2013; Hood and Malik 2013; Lucey and O'Connor 2013; Ming et al. 2020; Shahzad et al. 2019) and continues to gain popularity after the financial crisis (Baur and McDermott 2012; Maghyereh et al. 2017). Recently, the effectiveness of oil and gold as safe haven assets has been researched in Brazil, Russia, India, China, and South Africa (BRICS), which are oil-exporting countries and emerging nations in Asia (Abdullah et al. 2016; Maghyereh et al. 2017; Mensi 2019; Pandey 2018; Robiyanto 2018b; Robiyanto et al. 2019a, 2019b; Robiyanto et al. 2017; Shakil et al. 2018; Trabelsi 2017). However, the effectiveness of portfolio insurance strategy proxied by put replication has not been vastly researched.

(c) The Author(s). 2020 Open Access This article is licensed under a Creative Commons Attribution 4.0 International License, which permits use, sharing, adaptation, distribution and reproduction in any medium or format, as long as you give appropriate credit to the original author(s) and the source, provide a link to the Creative Commons licence, and indicate if changes were made. The images or other third party material in this article are included in the article's Creative Commons licence, unless indicated otherwise in a credit line to the material. If material is not included in the article's Creative Commons licence and your intended use is not permitted by statutory regulation or exceeds the permitted use, you will need to obtain permission directly from the copyright holder. To view a copy of this licence, visit http://creativecommons.org/licenses/by/4.0/. 
This study uses equities and commodities for portfolio construction due to the following reasons. First, Nugroho et al. (2018) showed that investing in equity is quite profitable. For instance, Indonesian Stock Market returns were the highest in Asia Pacific and fifth highest in the world in 2016. However, the previous study also showed that the level of capital market integration increased, implying that investors making investment diversification across ASEAN capital markets could only earn limited diversification advantages (Jarungkitkul and Sukcharoensin 2016; Karim and Ning 2013; Muharam et al. 2020; Thomas et al. 2017). They must therefore find other assets that can diversify their equity portfolios, especially in Indonesia, Malaysia, Singapore, Thailand, and the Philippines (ASEAN-5). Second, commodities like gold and oil have a weak correlation with equity and can be used to hedge and diversify the equity portfolio (Iglesias-Casal et al. 2020).

The main focus of this research is to analyze the usefulness of oil, gold, and bonds on hedging ASEAN-5 equities from the period January 2007 to December 2018. This period covers the financial crisis (Wen et al. 2019), the rise and subsequent fall of gold prices in 2010, and the recent oil crisis which began in mid-2014. The study specifically aims to measure the hedge effectiveness of oil on equities in ASEAN-5 countries as most Southeast Asian nations have been known as major oil consumers. Except for Malaysia, the other ASEAN-5 nations are net oil importers (Abdullah et al. 2016), and changes in crude oil prices can negatively impact these economies (Boonyasana 2018; Robiyanto 2018a). By investigating the dynamic correlations and volatilities between crude oil and equities markets, investors in ASEAN-5 stock markets can gain information about diversifying advantages.

Another objective of this research is to measure the hedge effectiveness of gold on equities. Gold investment is becoming attractive for investors due to their awareness of market risk in equity. This creates an opportunity for financial institutions to offer gold investment products, just as some Islamic and conventional banks in Malaysia have done. While previous research have shown that gold is good for hedging and risk reduction in severe market turbulence, investigation on this topic is relatively scarce in emerging Asian nations (Ghazali et al. 2015; Robiyanto 2018b). The final objective of this research is to measure the hedge effectiveness of the put replication strategy. Portfolio insurance methods gained popularity in the financial industry at the end of the 1970s. Rubinstein and Leland (1995) created option-based portfolio insurance (OBPI) by replicating options with a position in stock and cash. Perold and Sharpe (1988) introduced the constant proportion portfolio insurance (CPPI), which has gained popularity since it benefits investors by reducing downside risk while gaining upward possibility.

The rest of the study is structured as follows: Section 2 reviews the related literature and presents the hypotheses; Section 3 reveals the research method; Section 4 discusses the empirical findings; and Section 5 concludes the paper.

\section{Literature review and hypotheses development}

The asset allocation strategy in this research was mainly based on the modern portfolio theory suggested by Markowitz (1952). The theory suggested that the construction of a portfolio with different asset classes may reduce volatilities if returns of the assets have a minimal correlation. If the returns are perfectly correlated, then the creation of a 
portfolio cannot eliminate the risks. To reduce the risks, the portfolio that consists of assets with a high positive correlation must be avoided. Further, understanding the interdependencies of gold, oil, and equity is essential in developing the portfolio. Recently, gold and oil have been widely used as financial instruments, either for hedging or speculation, that increase the connection among markets (Arfaoui and Ben Rejeb 2017).

Gold is commonly known as a safe haven and widely used to diversify portfolios (Ciner et al. 2013; Zhu et al. 2017). Arfaoui and Ben Rejeb (2017) stated that the price of gold rises when the equity market falls during the crisis period. Wan et al. (2016) studied the contagious effects of oil prices on Asian stock markets' behavior and came up with the following findings regarding oil-stock relationship. First, the rise of oil prices can drive the stock market into turmoil since transportation and production costs may also increase. Stock markets in East Asia are interdependent when there is a negative shock on oil price, indicating that the diversification benefit is limited in the region. Second, negative shock on oil prices has a big effect on stock market volatility. Third, Hong Kong, South Korea, and Singapore are recommended as hedges for stock investing especially during negative oil shocks.

Le and Chang (2012) studied oil-gold relationship and found that the rise of oil prices can be accompanied by inflation, the role of gold as the inflationary hedge is improved. They also found that investors who have US dollar-based assets can use oil and gold, which have been priced in US dollars since 1975, to diversify portfolio risk. Hence, the volatility of the US dollar might make the price of oil and gold go in the same direction. In other words, when the value of the US dollar decreases, the purchasing power and demand for commodities may increase.

An option on a share could be replicated by a dynamic portfolio of a stock and position in cash which is invested in the risk-free rate. This approach is based on the Black-Scholes formula ("BS," hereafter). Beningga and Blume (1985) showed that if portfolio rebalancing is continuous, then the dynamic process is self-financing. It demands no additional cash flows after the construction of the initial portfolio. An investor at time 0 with wealth $\left(\mathrm{W}_{0}\right)$ can ensure his or her portfolio at $k$ by using some of the wealth to buy a share and the remainder to buy a European put. For instance, $S_{0}$ is the stock investment, and $\mathrm{P}_{0}$ the put price. In line with the BS formula, the stock price uses a Wiener process with expected return $\mu$ and standard deviation $\sigma$, and the riskfree rate is fixed at $r$. A put can be duplicated with the continuous portfolio rebalancing with a long position in the risk-free asset and a short position in the stock. Beningga and Blume (1985) also revealed that the synthetic put method demands the prediction of the future stock market volatility. However, Dichtl and Drobetz (2011) showed that volatility estimation errors do not have a large impact on portfolio values. They also stated that traditional portfolio insurance strategies stop-loss, synthetic put, and constant proportion portfolio insurance can protect the downside risk of the portfolio. Additionally, Jung (2016) stated that put replication for VIX futures can be utilized as a hedging tool for stock index, indicating that the positive yield from a protective put strategy can partly reduce loss. Based on this explanation, the first hypothesis for this study is as follows:

H1: Put replication can be utilized as downside risk protection on the stock portfolio.

Modern Portfolio Hypothesis (MPH) shows that risk reduction can be obtained when the assets of the portfolio do not correlate (Nugroho et al. 2018; Putra et al. 2018). 
Previous studies showed that gold can reduce the downside risk of the stock portfolio and be regarded as a safe haven. For instance, gold is not only a safe haven in oilimporting countries, but in oil-exporting countries as well. Baur and Lucey (2010) explained that gold could be used as a safe-haven asset in the US and Britain. On the other, Maghyereh et al. (2017) concluded that there is a very low and positive conditional correlation between gold and equities in oil-exporting nations, indicating that gold acts as a weak safe haven.

There are several possible explanations on why gold may provide hedging benefits. First, gold is an effective inflationary hedge (Hoang et al. 2016; Singh and Joshi 2019). Second, it can be utilized for gifts, marriage proposals, and social status improvement. Third, some central banks utilize it to stabilize macroeconomics (Agha et al. 2015). Fourth, the World Gold Council shows that when there is a $2 \%$ increase in inflation rate, there will be around a 5\% increase in gold demand (Liquidity in the Global Gold Market 2011). Fifth, paper-based gold investments such as exchange-traded funds (ETFs), have increased the popularity of gold. Based on this explanation, the second hypothesis of this study is as follows:

H2: Gold can limit the downside risk of the stock portfolio.

Pandey (2018) showed that there is volatility spillover from crude oil to equity; however, it is only significant post-crisis. Further, crude oil can be utilized for hedging equity market risk in South African and Russian equity markets. Trabelsi (2017) showed that the feedback of stock indices to oil shocks is noticeably positive, suggesting that the tail spillovers feedback is counting on the source of oil price shocks. Meanwhile, Arfaoui and Ben Rejeb (2017) showed that there are significant correlations between oil, gold, and stock prices. Oil price is undoubtedly affected by stock markets, and oil and gold are used as speculation or hedging, indicating that they have the characteristics of financial assets. These results suggest that the performance of these markets have become correlated with each other.

Boonyasana (2018) showed that Thailand's government issues an authorization to subsidize petroleum product prices. This action can adjust the impact of petroleum product prices on inflation, which may have a negative effect on investment. Further, Maghyereh et al. (2017) concluded that oil has very low and positive dynamic correlations with equities in Gulf Cooperation Council nations, implying that it is also a risky investment. The usual observation for volatility in stocks, such as leverage effect, can be found in oil as well. The authors also concluded that gold is a cheaper hedge in Gulf Cooperation Council nations. Based on the explanation, the third hypothesis of this study is as follows:

H3: Oil can limit the downside risk of the stock portfolio.

\section{Method}

\section{Data selection}

The equity indexes used in this study are the Straits Times Index (STI) for Singapore, Stock Exchange of Thailand (SET) for Thailand, KLSE Composite Index for Malaysia, Manila Composite Index (PSEI) for the Philippines, and the Indonesia Stock Exchange (JKSE) for Indonesia. The price of the index was obtained from Bloomberg and the risk-free rates of the ASEAN-5 nations were obtained from the central bank websites of 
each country. Further, the international gold price was sourced from www.kitco.com and West Texas Intermediate (WTI) data from the spot market at Cushing, Oklahoma were used. These represent the settlement price for the WTI crude futures on the New York Mercantile Exchange (Pandey 2018; Robiyanto 2018a).

The weekly price was divided based on the following timeframes. The crisis period is from 2007 to 2008, post-crisis is from 2009 to 2011, and the normal period is from 2012 to 2018. The timeframes are in line with previous studies concerning Asian capital market integration. The period from 2009 to 2011 was used as a post-crisis/recovery period because the risk-free interest rate was still relatively high. Furthermore, there is a global phenomenon that the price of gold stops increasing at the end of 2011 (Maghyereh et al. 2017).

The weekly returns were calculated as $r_{t}=100 \times\left(\ln P_{t}-\ln P_{t-1}\right)$ for $t=1,2, \ldots, 627$; where $r_{t}$ is the index return, $P_{t}$ is the equity index at time $t$, and $P_{t-1}$ is the equity index for $t-1$. The weekly data was used to avoid nonsynchronous trading and noisy events issues due to public holidays (Bala and Takimoto 2017). This research assumed that the initial value of 1000 was made at the beginning of the year (week 0 ) for each timeframe.

\section{Dynamic conditional correlation-generalized autoregressive conditional heteroscedasticity}

This research utilized the Dynamic Conditional Correlation (DCC) process proposed by Engle (2002). The method was used for the construction of the portfolio that consists of equities, gold, and oil in previous studies such as Arouri et al. (2014); Maghyereh et al. (2017); Robiyanto et al. (2019a, 2019b); Robiyanto et al. (2017). This model can capture time-varying and dynamic correlation using the return series without complex calculations. It is utilized for maintaining the flexibility of a univariate generalized autoregressive conditional heteroscedasticity (GARCH) model. With a large return series, the model was utilized to estimate the return series pairs separately. This allowed for the time-varying correlation and volatility to be obtained through the decomposition of the conditional matrix as follows:

If $r_{t}$ is an $\mathrm{n} \times 1$ vector of asset returns, an AR (1) process for $r_{t}$ can be depicted as:

$$
r_{t}=\mu+\alpha r_{t-1}+\varepsilon_{t}
$$

Residuals are processed with the following:

$$
\varepsilon_{t}=H_{t}^{1 / 2} z_{t}
$$

$H_{t}$ is the conditional covariance matrix of $r_{t}$ and $z_{t}$ is a $\mathrm{n} \times 1$ i.i.d random vector errors.

The DCC is a two-step process. It first estimates the GARCH parameters before measuring the conditional correlations:

$$
H_{t}=D_{t} R_{t} D_{t}
$$

$H_{t}$ is equal to the $\mathrm{n} \times \mathrm{n}$ conditional covariance matrix, $R_{t}$ is equal to the conditional covariance matrix, and $D_{t}$ is equal to a diagonal matrix with time-varying standard deviations. 
Concerning the GARCH $(1,1)$ model with $H$ as a diagonal matrix, the variables of $H_{t}$ can be formulated as:

$$
h_{t}=c+\alpha \varepsilon_{t-1}^{2}+b h_{t-1}
$$

$\alpha$ and $b$ are the ARCH/GARCH effects. Hence, DCC $(1,1)$ can be depicted in the following equation:

$$
Q_{t}=(1-\alpha-\beta) \bar{Q}+\alpha \varepsilon_{t-1} \varepsilon_{t-1}^{\prime}+\beta Q_{t-1}
$$

$\bar{Q}$ is the $n x n$ unconditional correlation matrix of the standardized residuals $Z_{i, t}$, where

$$
Z_{i, t}=\varepsilon_{i, t} / \sqrt{h_{i, t}}
$$

In addition, the DCC between assets $x$ and $y$ is given by:

$$
\rho_{x y, t}=\frac{q_{x y, t}}{\left(\sqrt{q_{x y, t} \sqrt{q_{x y, t}}}\right)}
$$

Further, the following formula measures the hedge ratio showing the amount where a long (buy) position of equity should be accompanied by a short or long position of $\beta_{x y}$, ${ }_{t}$ in oil or gold (Kroner and Sultan 1993):

$$
\beta_{x y, t}=\frac{\operatorname{Cov}\left(r_{x t}, r_{y t}\right)}{\operatorname{var}\left(\mathrm{r}_{y t}\right)}=\frac{h_{x y, t}}{h_{y y, t}}
$$

The conditional volatilities can be utilized to compute the portfolio weights that consist of equities and commodities (gold and oil) with the following formula (Kroner and Ng, 1998):

$$
w_{x y, t}=\frac{h_{y y, t}-h_{x y, t}}{h_{x x, t}-2 h_{x y, t}+h_{y y, t}}, \text { with } w_{x y, t}=\left\{\begin{array}{c}
0 \text { if } w_{x y, t}<0 \\
w_{x y, t} \text { if } 0 \leq w_{x y, t} \leq 1 \\
1, \text { if } w_{x y, t}>1 \\
\end{array}\right.
$$

where $w_{x y, t}$ is the proportion of asset $x$ at time $t$. The weight of asset $y$ is calculated as $1-w_{x y, t}$.

\section{Hedge effectiveness}

Hedging effectiveness (HE) was computed using the following formula:

$$
\text { Hedging Effectiveness }=\frac{\sigma^{2}{ }_{\text {unhedged }}-\sigma^{2} \text { hedged }}{\sigma^{2} \text { unhedged }}
$$


where $\sigma_{\text {hedged }}^{2}$ is the portfolio variance of bonds, oil or gold, and equity, and $\sigma^{2}$ unhedged is the portfolio variance of equity.

\section{Option-based portfolio insurance}

The option-based portfolio insurance (OBPI) is used for portfolio construction that consisted of equities and cash being invested at the risk-free rate. The protective put replication in this study originated from Beningga and Blume (1985). Using the BS formula, the portfolio consisting of put and stock is taking short or sell position stock and buying position on risk-free asset (jargon: bonds). The adjustment is made continuously. For instance, a put at $\mathrm{T}=1$ (expiration date) and $X$ (exercise price), the value is:

$$
\begin{aligned}
& P_{t}=-S_{t} N\left(-d_{1}\right)+X e^{-r(1-t)} N\left(-d_{2}\right) \\
& d_{1}=\frac{\ln \left(S_{t} / X\right)+\left(r+\sigma^{2} /{ }_{2}\right)(1-t)}{\sigma \sqrt{1-t}}, d_{2}=d_{1}-\sigma \sqrt{1-t}
\end{aligned}
$$

where $S_{t}$ is the stock or index price and 1- $t$ is time remaining, $r$ is the annualized riskfree interest rate, $\sigma$ is the standard deviation of the logarithm of the stock' $s$ return, and $N($.) represents a value of the standard normal distribution. It is assumed that the stock will pay no dividends before date t. Hence, $X e^{-r(1-t)} N\left(-d_{2}\right)$ indicates buying a put and $-S_{t} N\left(-d_{1}\right)$ shows a short (sell) position in the stock. The total investment (TI) is depicted in the following formula:

$$
T I=S_{t}+P_{t}=S_{t} N\left(d_{1}\right)+X e^{-r(1-t)} N\left(-d_{2}\right)
$$

The proportion of stock investment is:

$$
\omega=\frac{S_{t} N\left(d_{1}\right)}{S_{t} N\left(d_{1}\right)+X e^{-r(1-t)} N\left(-d_{2}\right)}
$$

The weight of risk-free asset (bonds) investment is:

$$
1-\omega=\frac{X e^{-r(1-t)} N\left(-d_{2}\right)}{S_{t} N\left(d_{1}\right)+X e^{-r(1-t)} N\left(-d_{2}\right)}
$$

The floor $(X)$ value of $90 \%$ of the total investment was used in this study. If an investor buys equities portfolio and wants to ensure that at $t=1$, the total investment will not be valued less than the floor $(X)$, then at each point in time $t$, the investor must invest a share $\omega$ of their wealth in a stock portfolio, and a share $1-\omega t$ in riskless, pure discount bonds that mature at $\mathrm{t}=1$. In other words, investors are assumed to invest in two assets: a money market account, $B$ for instance, and a composite index, $\mathrm{S}$. The period considered is $[0 ; \mathrm{T}]$. The strategies are self-financing; thus, the value of the riskless asset $B$ advances as stated by $d \mathrm{~B}_{\mathrm{t}}=\mathrm{B}_{\mathrm{t}} \mathrm{rdt}$, where $r$ is the acceptance interest rate. 
For the sake of simplification, the portfolio construction did not consider transaction costs.

\section{Performance analysis}

This research used the Sharpe ratio, drawdown, and Omega ratio for the performance analysis. The Sharpe ratio assumes that returns are normally distributed, while the omega ratio includes all the information in the returns distribution. The maximum drawdown is a measurement of portfolio returns from a peak to its trough over the sample period.

$$
S R=\frac{R-r f}{\sigma_{R}}
$$

where $S R$ is the Sharpe ratio, $R$ is the average return, $\mathrm{rf}$ is the risk-free rate, and $\sigma_{R}$ is the standard deviation.

$$
D_{t}=\max \left\{0, \underset{u=m+1, \ldots, t-1}{\max }\left(\sum_{i=m+1}^{u} R_{i}\right)-\sum_{i=m+1}^{t} R_{i}\right\}
$$

where $D_{t}$ is the drawdown, $\sum_{i=m+1}^{u} R_{i}$ is a sequence of partial sums of the out of sample portfolio returns from time $m+1$ to $t$.

$$
\Omega=\frac{\int_{r}^{b}(1-F(x)) d x}{\int_{r}^{b} F(x) d x}
$$

The Omega ratio $(\Omega)$ is the area above the threshold divided by the area below the threshold. The threshold value can be the risk-free rate.

\section{Robustness}

This research used the classical Markowitz (1952) mean-variance framework to calculate the minimum variance portfolio that consists of equities and commodities. Put replication strategy uses a riskless rate. As a consequence, the use of corporate or government bonds returns is not appropriate to construct a minimum variance portfolio that consists of equities and bonds for robustness tests. The researchers therefore only focused on gold and oil in this robustness test. Following Vo et al. (2019), the following is the optimization procedure:

$$
\min \sum_{i=1}^{n} \sum_{k=1}^{n} \sigma_{i, k} x_{i} x_{k}
$$

Subject to:

$$
\begin{aligned}
& \sum_{i=1}^{n} x_{i}=1 \\
& \sum_{i=1}^{n} r_{i} x_{i}=r_{p}
\end{aligned}
$$


Table 1 Descriptive statistics

\begin{tabular}{llllllll}
\hline & Gold & Oil & Indonesia & Malaysia & Philippines & Thailand & Singapore \\
\hline Mean (\%) & 0.15 & 0.03 & 0.20 & 0.07 & 0.15 & 0.13 & 0.01 \\
Med. (\%) & 0.23 & 0.18 & 0.36 & 0.18 & 0.25 & 0.35 & 0.16 \\
Max (\%) & 16.32 & 16.80 & 11.59 & 6.65 & 11.02 & 10.75 & 15.32 \\
Min (\%) & -11.43 & -17.07 & -23.30 & -9.71 & -20.15 & -26.66 & -16.47 \\
Std. Dev (\%) & 2.56 & 4.09 & 2.97 & 1.73 & 2.74 & 2.65 & 2.52 \\
Skewness (\%) & 22.53 & -4.16 & -129.98 & -81.94 & -94.90 & -185.11 & -38.05 \\
Kurtosis & 8.43 & 4.69 & 11.97 & 7.19 & 9.76 & 20.19 & 11.07 \\
JB & $774.75^{* * *}$ & $75.12^{* * *}$ & $2277.89^{* * *}$ & $528.06^{* * *}$ & $1287.86^{* * *}$ & $8074.04^{* * *}$ & $1715.04^{* * *}$ \\
Q(19) & $28.92^{*}$ & $75.46^{* * *}$ & $29.85^{*}$ & $29.32^{*}$ & $29.52^{*}$ & $47.75^{* * *}$ & $26.18^{*}$ \\
Obs**-squared & $22.64^{* * *}$ & $35.31^{* * *}$ & $8.49^{* * *}$ & $17.41^{* * *}$ & $7.03^{* * *}$ & $2.82^{*}$ & $29.76^{* * *}$ \\
$n$ & 627 & 627 & 627 & 627 & 627 & 627 & 627 \\
\hline
\end{tabular}

Notes: The table shows the descriptive stats for the weekly index returns as well as gold and oil

JB is the value of Jarque Bera for normality testing. $Q(19)$ is the q-stat of the correlogram test for serial correlation at 19 lags. The Obs*R-squared is the ARCH test

, " Statistical significance at $1 \%$ and $10 \%$

$$
0 \leq \mathrm{x}_{\mathrm{i}, \mathrm{i}} \mathrm{i}=1,2, \ldots, n
$$

where $r_{i}$ and $x_{i}$ are the returns and portfolio proportions respectively. $\sigma_{i, k}$ is the covariance and the asset weight is always positive.

\section{Results and discussion}

\section{Data description}

This study used 627 observations from a weekly data of stock indices, WTI oil future price (dollars per barrel), and gold price (dollars per ounce) from 2007 to the end of 2018. Following Maghyereh et al. (2017), the indices are in domestic currencies whereas the commodities are in US dollars since the main emphasis is on dynamic correlation. Table 1 shows that gold provides higher average weekly returns of 0.15 than oil, and Indonesia exhibits the highest average weekly returns. Furthermore, oil exhibits the highest risk. It is also interesting to note that gold has a positive skewness which is different from that of other markets. The correlogram q-stat with 19 lags exhibits the evidence of the serial correlation of all markets. In addition, all returns are not normally distributed. The table also shows that the Malaysian equity market has the lowest risk, and the Singaporean equity market has the lowest weekly returns. This study uses the

Table 2 Unit Root Test (Augmented Dickey-Fuller)

\begin{tabular}{lr}
\hline Variable & t-stat \\
\hline Gold & $-25.85^{\text {a }}$ \\
Oil & $-20.07^{\text {a }}$ \\
Indonesia & $-27.42^{\text {a }}$ \\
Malaysia & $-23.84^{\text {a }}$ \\
Philippines & $-26.81^{\text {a }}$ \\
Thailand & $-15.93^{\text {a }}$ \\
Singapore & $-15.55^{\text {a }}$ \\
\hline
\end{tabular}

Notes: The calculation is based on the Schwarz Info Criterion for lag length, at level, trend and intercept are included

a Statistical significance at $1 \%$ 
Table 3 Unconditional Correlation of Weekly Returns

\begin{tabular}{lllllll}
\hline Gold & Indonesia & Malaysia & Oil & Philippines & Thailand & Singapore \\
\hline 1 & 1 & & & & \\
0.049 & $0.617^{\mathrm{a}}$ & 1 & & & \\
0.010 & $0.120^{\mathrm{a}}$ & 0.064 & 1 & & \\
0.057 & $0.612^{\mathrm{a}}$ & $0.565^{\mathrm{a}}$ & $0.071^{\mathrm{b}}$ & 1 & 1 \\
0.040 & $0.569^{\mathrm{a}}$ & $0.509^{\mathrm{a}}$ & 0.061 & $0.538^{\mathrm{a}}$ & 1 \\
0.049 & $0.622^{\mathrm{a}}$ & $0.637^{\mathrm{a}}$ & $0.102^{\mathrm{a}}$ & $0.570^{\mathrm{a}}$ & $0.561^{\mathrm{a}}$ & 1 \\
-0.019 & & & & & \\
\hline
\end{tabular}

Notes: ${ }^{\mathrm{a}, \mathrm{b}}$ Statistical significance at $1 \%$ and $10 \%$

ARCH test to analyze the heteroscedasticity issue and Table 1 presents the result of the heteroscedasticity test of raw data before the implementation of GARCH $(1,1)$.

Table 2 exhibits a stationary test. The null hypothesis is that a unit root is apparent in the return data. The results show that $\mathrm{t}$-stats are not significant at the $1 \%$ level. Therefore, it is indicating that the presence of a unit root is rejected. As a result, the time series analysis can be further processed without having a spurious regression issue.

Table 3 shows that there is a possibility of risk minimization by constructing different assets in a portfolio since the return and risk correlation indicates various results. The unconditional correlation between equity markets in the ASEAN-5 is highly significant and consistent with the previous study from Arsyad (2015). Moreover, the correlation between commodities and equities is, on average, relatively low. This indicates that diversification benefits may be apparent at certain times. The low and positive correlation between commodities and equities may also provide limited hedging benefits.

Table 4 Diagnostic Test (DCC-GARCH)

\begin{tabular}{|c|c|c|c|c|c|c|c|c|c|c|c|c|c|}
\hline \multicolumn{14}{|c|}{ Autocorrelation test } \\
\hline \multicolumn{2}{|c|}{ Indonesia } & \multicolumn{2}{|c|}{ Malaysia } & \multicolumn{2}{|c|}{ Philippines } & \multicolumn{2}{|c|}{ Thailand } & \multicolumn{2}{|c|}{ Singapore } & \multicolumn{2}{|l|}{ Gold } & \multicolumn{2}{|l|}{ Oil } \\
\hline$Q(19)$ & $Q^{2}(19)$ & $Q(19)$ & $Q^{2}(19)$ & $Q(19)$ & $Q^{2}(19)$ & $Q(19)$ & $Q^{2}(19)$ & $Q(19)$ & $Q^{2}(19)$ & $Q(19)$ & $Q^{2}(19)$ & $Q(19)$ & $Q^{2}(19)$ \\
\hline 17.41 & 8.25 & 10.42 & 16.54 & 11.63 & 13.65 & 18.35 & 15.47 & 27.08 & 16.83 & 18.15 & 5.03 & 17.26 & 10.76 \\
\hline$(0.62)$ & $(0.99)$ & $(0.96)$ & $(0.68)$ & $(0.92)$ & $(0.84)$ & $(0.49)$ & $(0.74)$ & $(0.13)$ & $(0.66)$ & $(0.57)$ & (0.99) & $(0.57)$ & $(0.95)$ \\
\hline \multicolumn{14}{|c|}{ Variance equation } \\
\hline \multirow[t]{2}{*}{ c } & 0.00 & c & 0.00 & c & 0.00 & c & 0.00 & c & 0.00 & c & 0.00 & c & 0.00 \\
\hline & $(0.01)$ & & $(0.10)$ & & $(0.05)$ & & $(0.05)$ & & $(0.05)$ & & $(0.12)$ & & $(0.07)$ \\
\hline \multirow[t]{2}{*}{ a } & 0.26 & $a$ & 0.08 & $a$ & 0.09 & $a$ & 0.10 & $a$ & 0.13 & $a$ & 0.06 & $a$ & 0.09 \\
\hline & $(0.00)$ & & $(0.00)$ & & $(0.05)$ & & $(0.00)$ & & $(0.00)$ & & $(0.00)$ & & $(0.00)$ \\
\hline \multirow[t]{2}{*}{$b$} & 0.71 & $\mathrm{~b}$ & 0.90 & $b$ & 0.87 & $b$ & 0.88 & $\mathrm{~b}$ & 0.85 & $b$ & 0.91 & $b$ & 0.88 \\
\hline & $(0.00)$ & & $(0.00)$ & & $(0.00)$ & & $(0.00)$ & & $(0.00)$ & & $(0.00)$ & & $(0.00)$ \\
\hline$\lambda$ & 0.97 & $\lambda$ & 0.98 & $\lambda$ & 0.96 & $\lambda$ & 0.98 & $\lambda$ & 0.98 & $\lambda$ & 0.97 & $\lambda$ & 0.97 \\
\hline \multicolumn{14}{|c|}{ Heteroscedasticity test } \\
\hline \multicolumn{2}{|c|}{$\begin{array}{l}\text { ARCH-LM } \\
(19)=7.86\end{array}$} & \multicolumn{2}{|c|}{$\begin{array}{l}\text { ARCH-LM } \\
(19)=18.536\end{array}$} & \multicolumn{2}{|c|}{$\begin{array}{l}\text { ARCH-LM } \\
(19)=14.721\end{array}$} & \multicolumn{2}{|c|}{$\begin{array}{l}\text { ARCH-LM } \\
(19)=14.26\end{array}$} & \multicolumn{2}{|c|}{$\begin{array}{l}\text { ARCH-LM } \\
(19)=20.451\end{array}$} & \multicolumn{2}{|c|}{$\begin{array}{l}\text { ARCH-LM } \\
(19)=4.45\end{array}$} & \multicolumn{2}{|c|}{$\begin{array}{l}\text { ARCH-LM } \\
(19)=11.04\end{array}$} \\
\hline
\end{tabular}

Notes: This table represents the Q-stats of correlogram and residual squared test for autocorrelation test. The $\rho-$ values are in parentheses. The heteroscedasticity test (Obs* R-squared value) is ARCH-LM with 19 lags. $a$ and $b$ are the ARCH/ GARCH effects and $\lambda$ is the volatility persistence. The GARCH $(1,1)$ is used 
Table 5 Portfolio Performance

\begin{tabular}{|c|c|c|c|c|}
\hline & Put Replication & Gold - Hedged & Oil - Hedged & Uninsured \\
\hline \multicolumn{5}{|l|}{ Crisis } \\
\hline \multicolumn{5}{|l|}{ Indonesia: } \\
\hline HE & 0.653 & 0.586 & 0.374 & 0.000 \\
\hline SR & 0.078 & 0.070 & -0.089 & -0.079 \\
\hline Drawdown & -0.134 & -0.169 & -0.341 & -0.379 \\
\hline Omega & 1.081 & 0.976 & 0.891 & 1.065 \\
\hline \multicolumn{5}{|l|}{ Malaysia: } \\
\hline $\mathrm{HE}$ & 0.999 & 0.379 & -0.091 & 0.000 \\
\hline SR & 0.017 & 0.057 & -0.093 & -0.068 \\
\hline Drawdown & -0.091 & -0.063 & -0.272 & -0.240 \\
\hline Omega & 1.197 & 1.110 & 0.764 & 0.800 \\
\hline \multicolumn{5}{|l|}{ Philippines: } \\
\hline $\mathrm{HE}$ & 1.000 & 0.596 & 0.369 & 0.000 \\
\hline$S R$ & -0.011 & 0.013 & -0.084 & -0.103 \\
\hline Drawdown & -0.105 & -0.116 & -0.283 & -0.440 \\
\hline Omega & 0.991 & 0.964 & 0.775 & 0.753 \\
\hline \multicolumn{5}{|l|}{ Thailand } \\
\hline $\mathrm{HE}$ & 1.000 & 0.581 & 0.218 & 0.000 \\
\hline$S R$ & 0.042 & 0.001 & -0.116 & -0.091 \\
\hline Drawdown & -0.057 & -0.143 & -0.377 & -0.382 \\
\hline Omega & 1.124 & 0.996 & 0.714 & 0.816 \\
\hline \multicolumn{5}{|l|}{ Singapore: } \\
\hline HE & 1.000 & 0.616 & 0.285 & 0.000 \\
\hline$S R$ & -0.019 & -0.011 & -0.123 & -0.115 \\
\hline Drawdown & -0.066 & -0.189 & -0.386 & -0.570 \\
\hline Omega & 0.945 & 0.921 & 0.688 & 0.691 \\
\hline \multicolumn{5}{|l|}{ Post-crisis } \\
\hline \multicolumn{5}{|l|}{ Indonesia: } \\
\hline HE & 0.862 & 0.434 & 0.151 & 0.000 \\
\hline$S R$ & 0.210 & 0.251 & 0.245 & 0.212 \\
\hline Drawdown & -0.096 & -0.085 & -0.106 & -0.051 \\
\hline Omega & 1.788 & 1.883 & 1.810 & 1.947 \\
\hline \multicolumn{5}{|l|}{ Malaysia: } \\
\hline $\mathrm{HE}$ & 0.939 & 0.099 & -1.369 & 0.000 \\
\hline$S R$ & 0.215 & 0.252 & 0.301 & 0.205 \\
\hline Drawdown & -0.046 & -0.052 & -0.091 & -0.056 \\
\hline Omega & 1.714 & 1.896 & 1.759 & 1.761 \\
\hline \multicolumn{5}{|l|}{ Philippines: } \\
\hline $\mathrm{HE}$ & 0.384 & 0.481 & -0.021 & 0.000 \\
\hline$S R$ & 0.199 & 0.245 & 0.225 & 0.194 \\
\hline Drawdown & -0.061 & -0.083 & -0.110 & -0.057 \\
\hline Omega & 1.696 & 1.854 & 1.716 & 1.789 \\
\hline \multicolumn{5}{|l|}{ Thailand: } \\
\hline $\mathrm{HE}$ & 0.941 & 0.400 & -0.030 & 0.000 \\
\hline
\end{tabular}


Table 5 Portfolio Performance (Continued)

\begin{tabular}{|c|c|c|c|c|}
\hline & Put Replication & Gold - Hedged & Oil - Hedged & Uninsured \\
\hline$S R$ & 0.202 & 0.222 & 0.214 & 0.196 \\
\hline Drawdown & -0.062 & -0.080 & -0.063 & -0.068 \\
\hline Omega & 1.714 & 1.769 & 1.681 & 1.816 \\
\hline \multicolumn{5}{|l|}{ Singapore: } \\
\hline $\mathrm{HE}$ & 0.992 & 0.481 & 0.020 & 0.000 \\
\hline$S R$ & 0.104 & 0.260 & 0.167 & 0.188 \\
\hline Drawdown & -0.109 & -0.078 & -0.101 & -0.184 \\
\hline Omega & 1.362 & 1.533 & 1.497 & 1.384 \\
\hline \multicolumn{5}{|l|}{ Normal } \\
\hline \multicolumn{5}{|l|}{ Indonesia: } \\
\hline $\mathrm{HE}$ & 0.370 & 0.500 & -0.184 & 0.000 \\
\hline SR & 0.040 & 0.034 & -0.012 & 0.068 \\
\hline Drawdown & -0.076 & -0.133 & -0.433 & -0.074 \\
\hline Omega & 1.216 & 1.059 & 0.943 & 1.232 \\
\hline \multicolumn{5}{|l|}{ Malaysia: } \\
\hline HE & 0.954 & -0.047 & -1.800 & 0.000 \\
\hline$S R$ & 0.017 & -0.003 & -0.034 & 0.019 \\
\hline Drawdown & -0.041 & -0.131 & -0.438 & -0.046 \\
\hline Omega & 1.043 & 0.975 & 0.897 & 1.077 \\
\hline \multicolumn{5}{|l|}{ Philippines: } \\
\hline HE & 0.979 & 0.455 & -0.188 & 0.000 \\
\hline$S R$ & 0.067 & 0.037 & -0.008 & 0.077 \\
\hline Drawdown & -0.050 & -0.064 & -0.378 & -0.048 \\
\hline Omega & 1.192 & 1.057 & 0.946 & 1.256 \\
\hline \multicolumn{5}{|l|}{ Thailand: } \\
\hline $\mathrm{HE}$ & 0.992 & 0.420 & -0.409 & 0.000 \\
\hline$S R$ & 0.042 & 0.035 & -0.011 & 0.063 \\
\hline Drawdown & -0.067 & -0.060 & -0.410 & -0.055 \\
\hline Omega & 1.200 & 1.063 & 0.946 & 1.226 \\
\hline \multicolumn{5}{|l|}{ Singapore: } \\
\hline HE & 0.997 & 0.322 & -0.782 & 0.000 \\
\hline$S R$ & 0.022 & 0.004 & -0.032 & 0.024 \\
\hline Drawdown & -0.036 & -0.186 & -0.486 & -0.042 \\
\hline Omega & 1.065 & 0.976 & 0.891 & 1.081 \\
\hline \multicolumn{5}{|l|}{ Full Sample } \\
\hline \multicolumn{5}{|l|}{ Indonesia: } \\
\hline $\mathrm{HE}$ & 0.517 & 0.507 & 0.113 & 0.000 \\
\hline$S R$ & 0.109 & 0.118 & 0.048 & 0.067 \\
\hline Drawdown & -0.102 & -0.129 & -0.293 & -0.168 \\
\hline Omega & 1.429 & 1.302 & 1.169 & 1.350 \\
\hline \multicolumn{5}{|l|}{ Malaysia: } \\
\hline $\mathrm{HE}$ & 0.964 & 0.144 & -1.087 & 0.000 \\
\hline SR & 0.083 & 0.102 & 0.058 & 0.052 \\
\hline Drawdown & -0.059 & -0.082 & -0.267 & -0.114 \\
\hline
\end{tabular}


Table 5 Portfolio Performance (Continued)

\begin{tabular}{|c|c|c|c|c|}
\hline & Put Replication & Gold - Hedged & Oil - Hedged & Uninsured \\
\hline Omega & 1.318 & 1.327 & 1.140 & 1.213 \\
\hline \multicolumn{5}{|l|}{ Philippines: } \\
\hline $\mathrm{HE}$ & 0.599 & 0.511 & 0.054 & 0.000 \\
\hline SR & 0.085 & 0.099 & 0.044 & 0.056 \\
\hline Drawdown & -0.072 & -0.087 & -0.257 & -0.182 \\
\hline Omega & 1.293 & 1.291 & 1.146 & 1.266 \\
\hline \multicolumn{5}{|l|}{ Thailand: } \\
\hline $\mathrm{HE}$ & 0.978 & 0.467 & -0.074 & 0.000 \\
\hline$S R$ & 0.086 & 0.096 & 0.029 & 0.056 \\
\hline Drawdown & -0.062 & -0.094 & -0.283 & -0.168 \\
\hline Omega & 1.346 & 1.276 & 1.114 & 1.286 \\
\hline \multicolumn{5}{|l|}{ Singapore: } \\
\hline HE & 0.996 & 0.473 & -0.159 & 0.000 \\
\hline$S R$ & 0.036 & 0.084 & 0.004 & 0.033 \\
\hline Drawdown & -0.070 & -0.151 & -0.324 & -0.265 \\
\hline Omega & 1.124 & 1.188 & 1.111 & 1.240 \\
\hline
\end{tabular}

Notes: This table shows the hedge effectiveness (HE), Sharpe ratio (SR), drawdown, and Omega ratio results The bolded numbers represent the best performances

Nevertheless, the unconditional correlation cannot be efficiently used since the returns have dynamic volatilities and covariances. Therefore, the DCC GARCH is utilized.

Table 4 provides the results of the diagnostic test. The q-stat of correlogram is used to test whether an autocorrelation issue exists. If all the $\rho$ values of the 19 lags are statistically significant at $5 \%$, the autocorrelation may exist. In addition, this study implemented the ARCH-LM test to analyze the heteroscedasticity issue. Similar to Q-stat, 19 lags were used. The $\rho$ values of the 19 lags from q-stats show that the numbers are greater than $5 \%$, indicating that the autocorrelation may not exist. Based on the results, the GARCH model is fit.

Further, Table 4 also shows the volatility persistence and ARCH/GARCH effect, which are based on the variance equation. The closer the volatility persistence $(\lambda)$ to one, the longer the unpredictable pattern in the future. Similar to previous studies, this study utilized DCC-GARCH (1,1) (Maghyereh et al. 2017; Zhao et al. 2018). The value of $\alpha$ is to measure the sensitivity of the equity market to new information, while the value of $b$ is to measure the conditional variance and is impacted by the lag length. In Table 4, the $\lambda$ values of all markets are closer to one, showing that the volatility pattern of all markets will persist in the future. Meanwhile, the $b$ values of Malaysian equities and the gold market are greater than the other markets, indicating that a relatively faster degree of decline in those markets.

Table 5 exhibits the HE, SR, drawdown, and omega values during the crisis, postcrisis, normal period, and in all samples. The higher the HE values, the better the protection. In addition, the table exhibits the return of investment involving riskadjustment measures. During the crisis, the put replication strategy provides a better risk-adjusted return compared to other strategies in Indonesia and Thailand. Meanwhile, a gold-hedged portfolio exhibits better risk-adjusted performance compared to the oil-hedged strategy during the crisis. Overall, the gold-hedged portfolio is the best 
performer in Malaysia, the Philippines, and Singapore, and put replication is the best strategy in Indonesia and Thailand during the crisis period. Further, the put replication strategy has the best HE, while gold-hedged and oil-hedged strategies provide low HE during the crisis period. During post-crisis, a gold-hedged strategy exhibits greater riskadjusted-performance.

Furthermore, the uninsured equities portfolio exhibits bigger risk-adjusted performance in the Philippines, Thailand, Malaysia, and Singapore, and put replication strategy offers a better risk-adjusted return in Indonesia under normal conditions. Another noticeable result is that the oil-hedged strategy offers the worst riskadjusted return compared to other strategies under normal market conditions. Moreover, this strategy also provides the worst HE under normal conditions. Interestingly, gold offers the best HE in Indonesia compared to the put replication strategy, whereas the latter exhibits the best HE in Malaysia, Thailand, Singapore, and the Philippines under normal conditions. Further, the traditional Sharpe ratio shows that the gold-hedged strategy offers better performance in Malaysia, the Philippines, and Singapore in crisis periods because the average DCC is negative between gold and equity except for Indonesia and Thailand.

The drawdown and Omega ratio results are mixed across nations. On one hand, the put replication provides a better drawdown performance in Indonesia, Thailand, and Singapore in the crisis period. For instance, the drawdown performance for put replication in Indonesia during the crisis period is -0.134 compared to -0.169 in the goldhedged strategy, indicating that the maximum sequence loss of the portfolio value in the put replication strategy is lower than the gold-hedged strategy. On the other hand, the Omega ratio shows that gold provides a better hedging performance for equity in Malaysia, the Philippines, and Singapore in the post-crisis period. On average, based on the Omega ratio in the overall sample period, the put replication strategy provides better performance in Indonesia, the Philippines, and Thailand. As for Malaysia and all equity portfolios in Singapore, the Omega ratio shows better performance for goldhedged strategy.

The reason that the gold-hedged strategy is highly recommended in Malaysia could be due to, the launching of gold bullion coins, Kijang Emas, followed by several gold Dinars, that has provided investors with an alternative investment (Ibrahim 2012). Interestingly, the all-equity stock portfolio in Singapore offers better performance than other strategies since its capital market is the most advanced in Southeast Asia. This is in line with the research of Wan et al. (2016), who suggested that Hong Kong, South Korea, and Singapore are recommended as hedges for stock investing especially during negative oil shocks. Arsyad (2015) studied equity market co-movements between East and Southeast Asia and found that random shocks from Singapore have a higher influence on Southeast Asian exchanges. Moreover, the results of the omega ratio across nations are different from the Sharpe ratio because the former includes all the information in the returns distribution, while the latter assumes that returns are normally distributed.

Table 5 shows that the put replication strategy is the best when considering the maximum sequence loss (drawdown) overall sample period. However, when the market is in extreme turmoil, the gold-hedged strategy provides better performance than the put replication strategy in Malaysia. 
Figure 1 shows the portfolio value from the crisis to the normal period. When the financial crisis started in September 2008, the equity-gold portfolio has a better portfolio value than the equity-oil portfolio towards the end of 2008. Additionally, the put replication strategy has the best portfolio value compared to the oil-hedged, gold-hedged, and uninsured or unhedged portfolio from September to December 2008. This result indicates that bonds or money market instruments are the most feasible assets to be kept during extreme market turbulence in emerging nations in Asia. The equity-oil portfolio has the best portfolio values during the post-crisis (recovery) period, but the worst portfolio value during the normal period. Moreover, during the normal period, the unhedged or uninsured portfolio value is the best performer followed by the put replication strategy. However, the results from Fig. 1 are based on the value of the portfolio at the end of each timeframe and do not account for risk adjustment measures such as the variability of returns. Therefore, the researchers calculated risk-adjusted performance using the Sharpe Ratio (SR) as in Table 5.

Based on the above-mentioned explanation, all three hypotheses are accepted. The put replication can be utilized as downside risk protection on the stock portfolio, and both gold and oil can limit the downside risk of the stock portfolio.

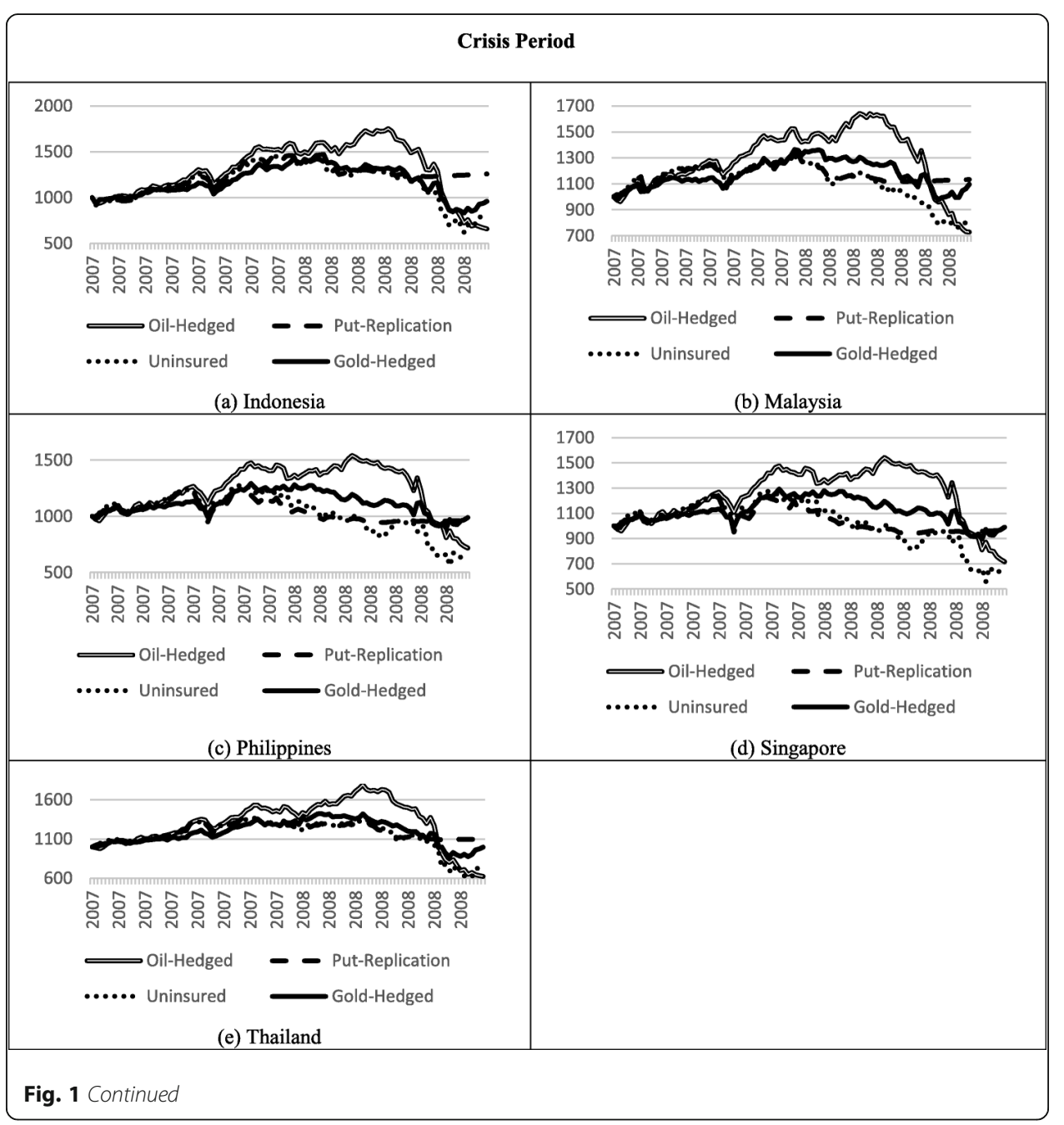




\begin{tabular}{|c|c|}
\hline \multicolumn{2}{|c|}{ Post-Crisis (Recovery) Period } \\
\hline 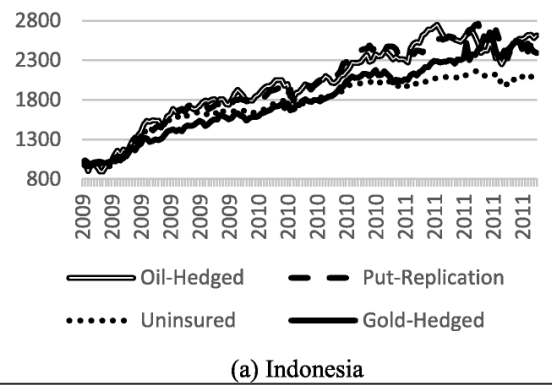 & 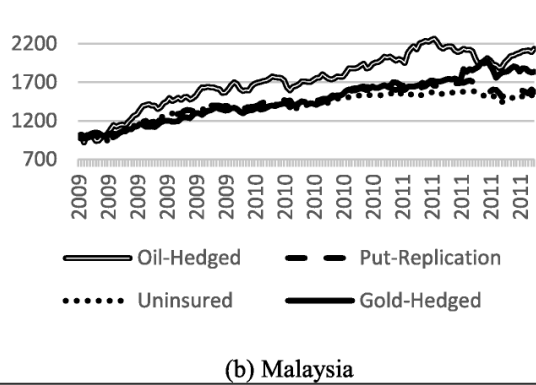 \\
\hline 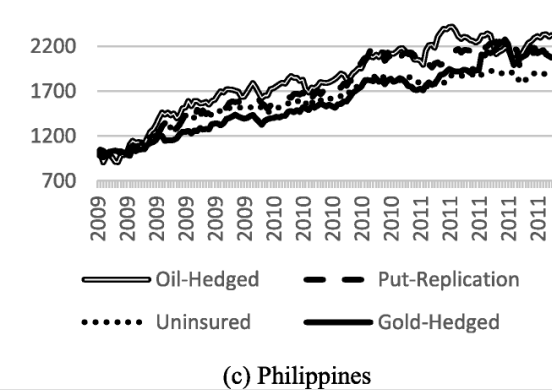 & $\begin{array}{l}2800 \\
1300 \\
\text {...... Uninsured } \\
\text { (d) Singapore }\end{array}$ \\
\hline 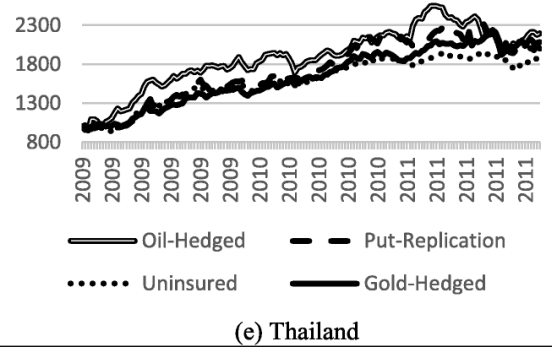 & \\
\hline & \\
\hline
\end{tabular}




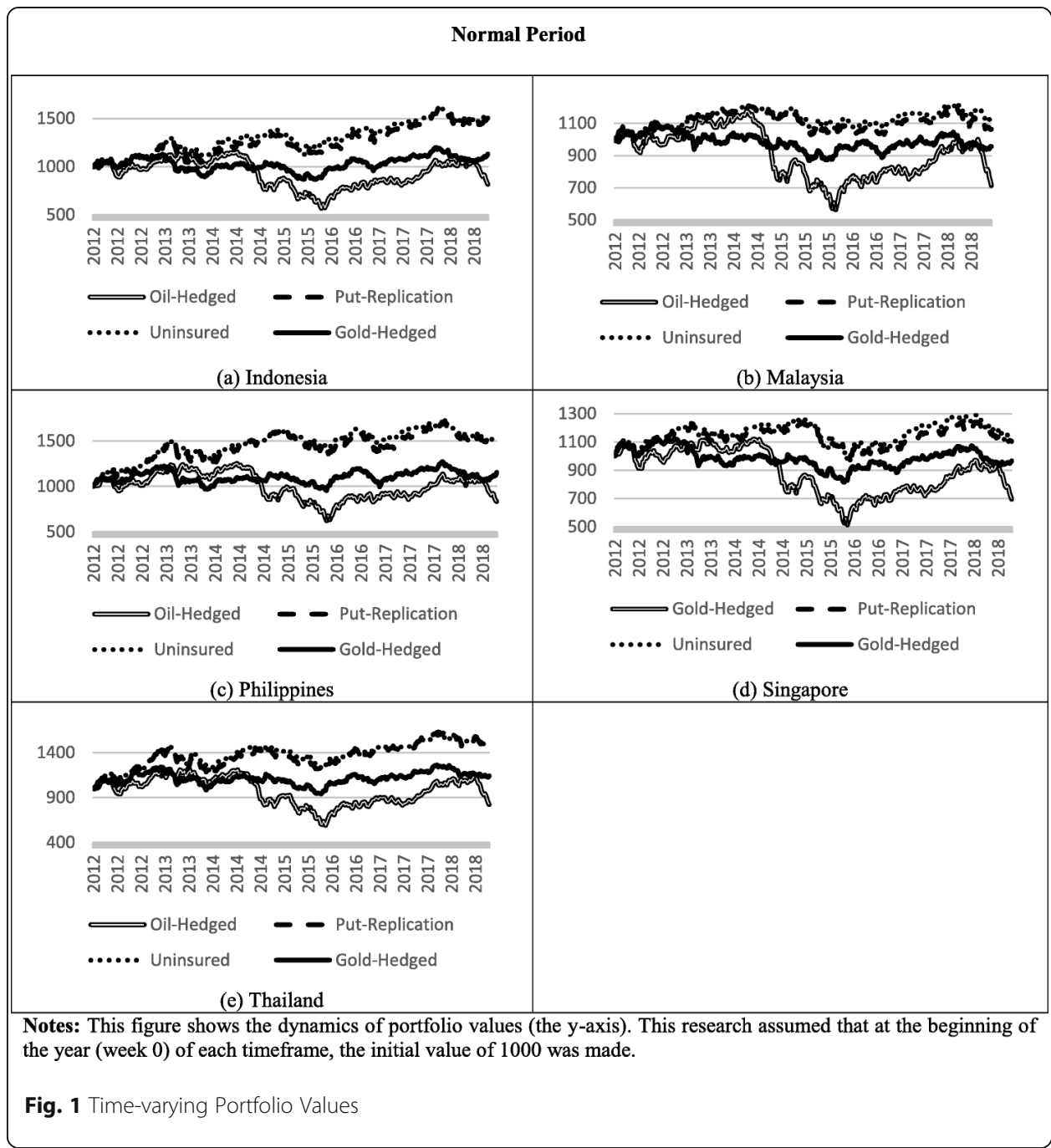

\section{Implications}

Based on the time-varying condition correlation and the HE, oil can be regarded as a weak safe haven. This signifies that it is not just a global commodity, but also plays a role in the financial market. This finding is in line with Ciner et al. (2013) who suggested that oil is a weak safe haven for a major decline in the US bonds market. Oil is also a safe haven particularly during the credit crunch that took place after 2009 . However, the role of oil as a financial asset is smaller than that of gold since the HE of oil is less, especially during the financial crisis. Moreover, consistent with previous studies done by Creti et al. (2013); Maghyereh et al. (2017), the volatilities of the equity and commodities correlation are more prevalent during the financial crisis and more stable after 2010, suggesting that frequent portfolio rebalancing is required due to the changing of investor preference. As seen in Fig. 2, on average, the dynamic correlations of oil and equities are very low and positive. This result is aligned with Awartani and Maghyereh (2013); Filis et al. (2011); Maghyereh et al. (2017); Robiyanto (2018a).

Since most of the ASEAN-5 countries are net importers of oil, government policy has played an important role in controlling petroleum-related products (Abdullah et al. 


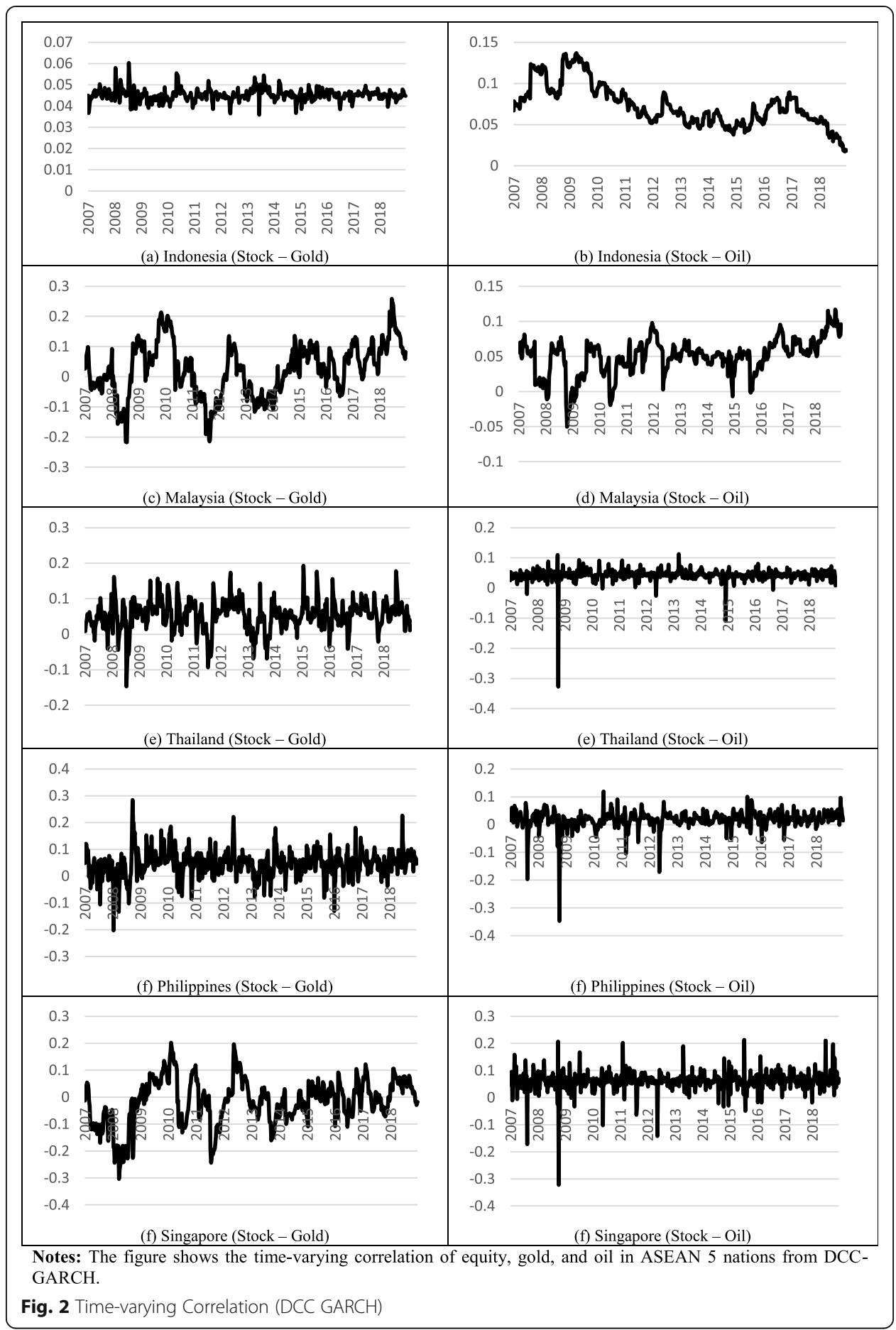

2016). This makes nations extremely vulnerable to price fluctuations in international markets because most of their energy consumption originates from petroleum products. For example, Thailand and Indonesia have controlled the consumption of petroleum products with taxes and subsidies (Boonyasana 2018). As a consequence, oil prices have affected economic growth (Hersugondo et al. 2015; Soyemi et al. 2017). Figure 2 shows that the Philippines equity has the lowest dynamic condition correlation with oil; 
Table 6 Hedge Ratio - Full Sample

\begin{tabular}{lr}
\hline Indonesia - Gold & 0.051 \\
Malaysia - Gold & 0.028 \\
Philippines - Gold & 0.048 \\
Thailand - Gold & 0.071 \\
Singapore - Gold & 0.018 \\
Indonesia - Oil & 0.097 \\
Malaysia - Oil & 0.231 \\
Philippines - Oil & 0.163 \\
Thailand - Oil & 0.245 \\
Singapore - Oil & 0.257
\end{tabular}

Notes: This table is hedge ratio of equities - commodities portfolio based on DCC-GARCH

this is in line with the results of Abdullah et al. (2016). This suggests that investors who have big exposure to oil should diversify to Philippine equities. Abdullah et al. (2016) also stated that incorporating the Philippine Islamic stock index into an oilrelated portfolio can create diversification opportunities in the short-term period.

The DCC in Fig. 2 exhibits that gold has very low and positive dynamic correlations with equities in ASEAN-5 nations. On average, the biggest dynamic correlation between gold and equities is in Thailand, which is 0.05 . Hence, the result of the timevarying conditional correlation implies that gold is a weak safe haven. This finding supports Ghazali et al. (2015). There are two possible reasons why gold is not a strong safe haven. Firstly, the volatility of gold returns indicates that it is a risky investment. The usual observation for volatility in stocks, such as the leverage effect, can be found in gold as well. Secondly, gold and stock index can produce a certain degree of comovement, reducing the safe haven ability of gold. This finding is also consistent with Maghyereh et al. (2017) who found that oil and gold are weak safe havens for stock markets in Gulf Cooperation Council nations.

The put replication strategy is found to be the best strategy in the crisis period. This result indicates that bond markets sustain the traditional role as a hedge for the equities, at least on average. While this result is consistent with Ciner et al. (2013), however, this result is also in line with Robiyanto et al. (2019a, 2019b) who suggested that government bonds are not simply diversifier instruments, but also have roles as a safe haven and hedge in the Indonesian capital market. This condition may exist since Indonesian and Malaysian government bonds are in demand by foreign investors (Gusdinar and Koesrindartoto 2013). For instance, by October 2015, the portion of foreigners' ownership of Indonesian government bonds was 37\%, while it was $33.8 \%$ for Malaysian government bonds. This is a $29.7 \%$ increase from the previous year (Robiyanto 2018b).

Table 6 shows the hedge ratio results for all samples, while Fig. 3 depicts the timevarying hedge ratios. Positive values indicate that investors should take a short (sell) position on commodities. For example, the hedge ratio of equity-gold portfolio is 0.051 , indicating that investing in 1 USD in the Indonesian index can be hedged with a short position of 5 cents of gold. Similarly, the hedge ratio of equity-oil portfolio is 0.145 , indicating that investing in 1 USD in the Malaysian index can be hedged with a short position 


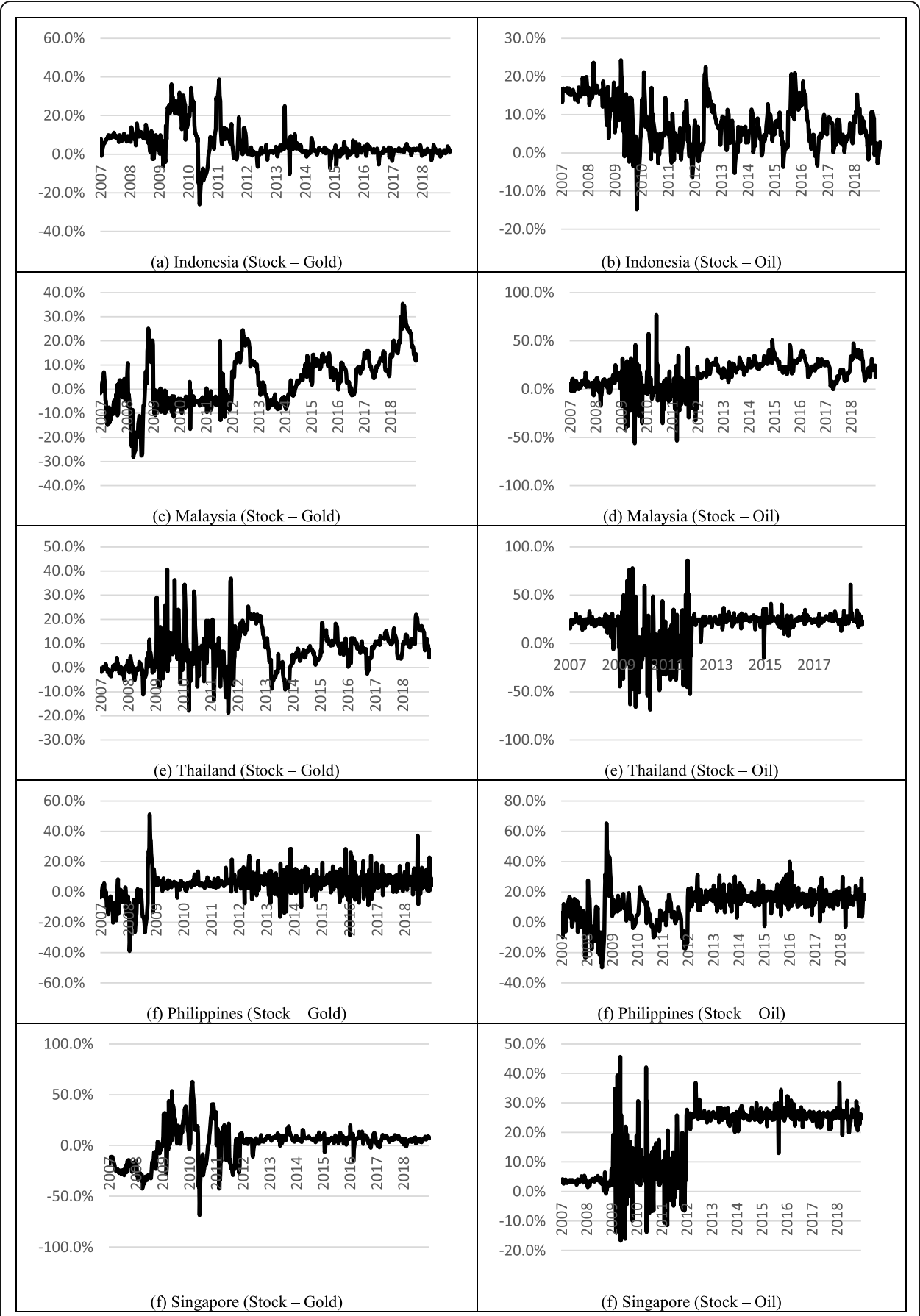

Notes: The figure shows the dynamic hedge ratios of equity, gold, and oil in ASEAN 5 nations from DCC-GARCH. The $\mathrm{y}$-axis is the hedge ratios.

Fig. 3 Dynamic Hedge Ratios (DCC GARCH)

of 14 cents of oil contract futures. On average, gold is a cheaper hedge than oil, supporting the finding of Maghyereh et al. (2017). However, the oil-hedged strategy is more expensive in ASEAN-5 nations compared to Gulf Cooperation Council nations. The average hedge ratio for oil is 5 cents in Gulf Cooperation Council nations, while it is 14 cents in ASEAN-5 nations, indicating that hedging equity using oil futures contracts in oil- 


\begin{tabular}{|c|c|c|}
\hline 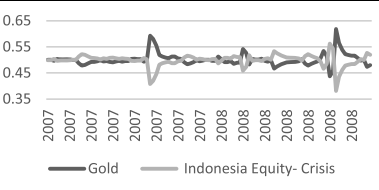 & 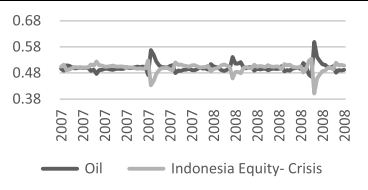 & 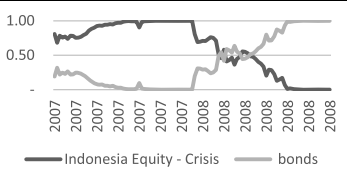 \\
\hline 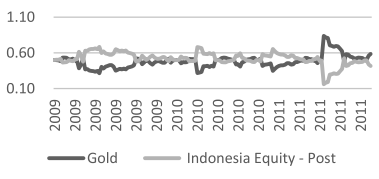 & 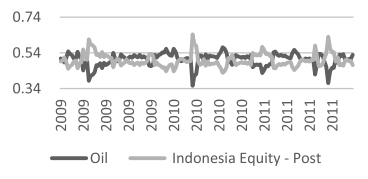 & 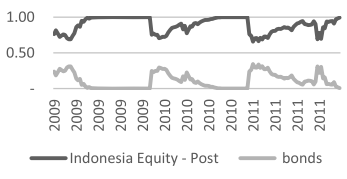 \\
\hline 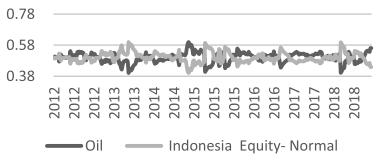 & 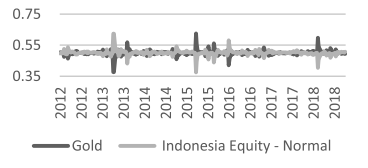 & $\begin{array}{l}1.00 \\
0.50 \\
\text { —indonesia Equity - Normal — bonds }\end{array}$ \\
\hline $\begin{array}{l}0.70 \\
0.50 \\
0.40 \\
0.30 \\
\text { —Gold — Malaysia Equity-Crisis }\end{array}$ & 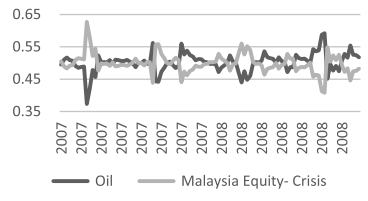 & —Malaysia Equity-Crisis— Bonds \\
\hline 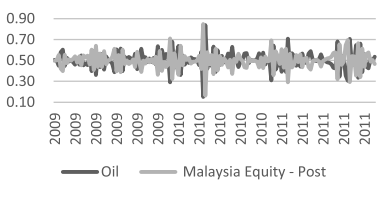 & 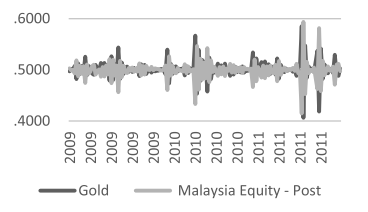 & 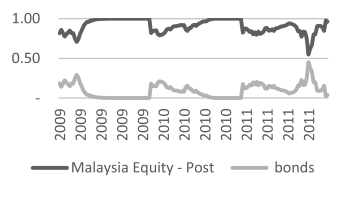 \\
\hline 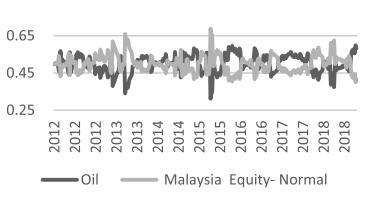 & 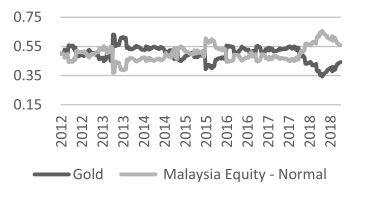 & $\begin{array}{l}0.00 \text { - } \\
\text { —Malaysia Equity- Normal. }\end{array}$ \\
\hline 0.70 Cold & $\begin{array}{l}1.00 \\
0.50 \\
\text { — oil — Thailand Equity- Crisis }\end{array}$ & —Thailand Equity-Crisis—Bonds \\
\hline 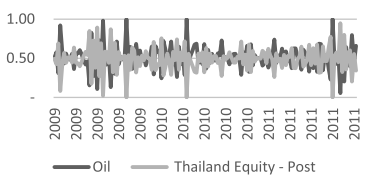 & 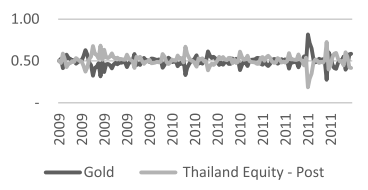 & 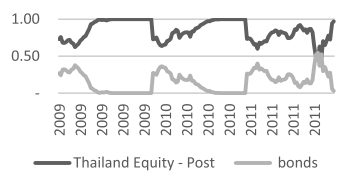 \\
\hline 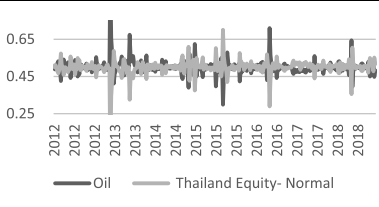 & $\begin{array}{l}0.65 \\
0.55 \\
0.45 \\
0.35 \\
\text { — Gold — Thailand Equity - Normal }\end{array}$ & 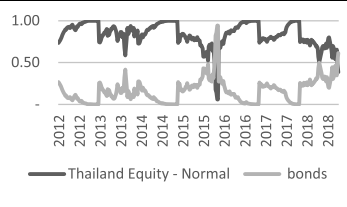 \\
\hline 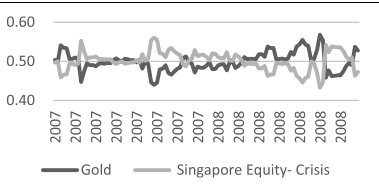 & 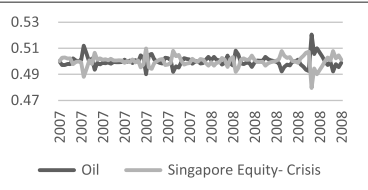 & —Singapore Equity - Crisis — Bonds \\
\hline
\end{tabular}

Fig. 4 Continued 


\begin{tabular}{|c|c|c|}
\hline 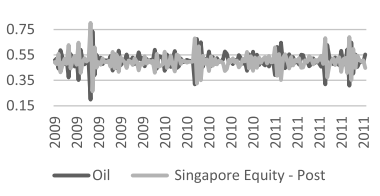 & $\begin{array}{l}0.50 \text { Shoo } \\
\text { — Gold — singapore Equity - Post }\end{array}$ & 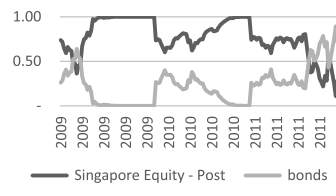 \\
\hline 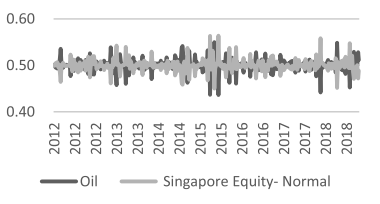 & 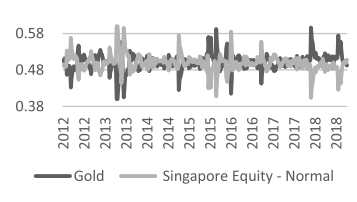 & 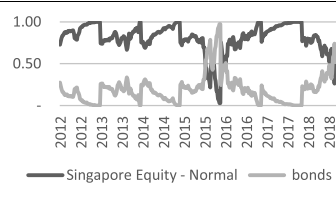 \\
\hline $\begin{array}{l}0.90 \\
0.70 \\
0.50 \\
0.30 \\
0.10\end{array}$ & 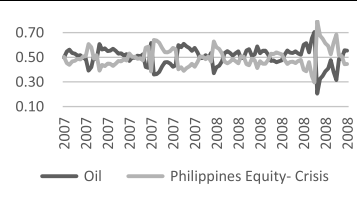 & $\begin{array}{l}0.50 \\
\text { —Philippines Equity - Crisis }\end{array}$ \\
\hline 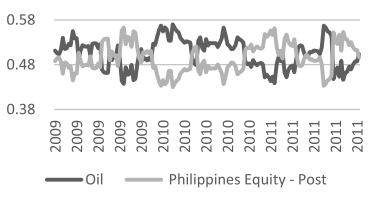 & 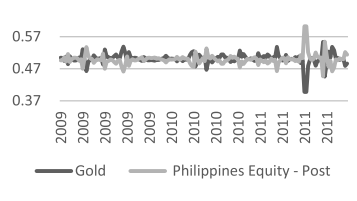 & 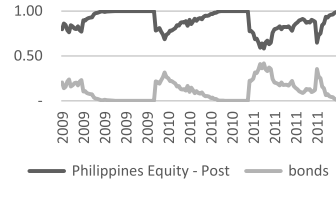 \\
\hline 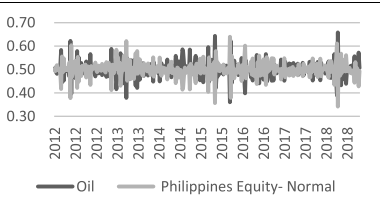 & 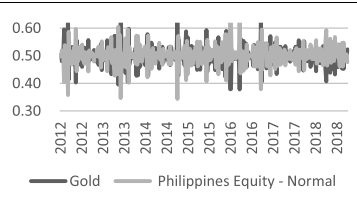 & 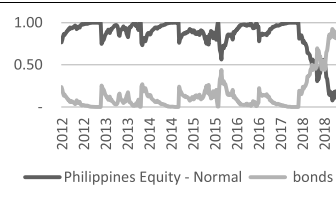 \\
\hline $\begin{array}{l}\text { e: Post is the post-crisis period, crisis is the crisis } \\
\text { rce: Authors Calculation } \\
\mathbf{4} \text { Time-varying Optimal Weight }\end{array}$ & ind normal is the normal period & \\
\hline
\end{tabular}


Table 7 Selected Recent Studies' Findings Versus This Research's Findings

\begin{tabular}{ll}
\hline Authors & Methodology \\
Ibrahim & An autoregressive distributed \\
& lag model was used. There \\
& were 2261 daily observations \\
& spanning from August 1, 2001 \\
& to March 31, 2010. Domestic \\
& gold bullion and the Kuala \\
& Lumpur composite index are \\
& used. \\
& \\
& \\
& \\
Robiyanto & The authors used monthly \\
et al. (2017) & closing prices of the \\
& Indonesian and Malaysian \\
& stock exchanges and gold, \\
& silver, platinum, and palladium \\
& from the international markets \\
& from January 1999 to July \\
& 2014. The DCC-GARCH was \\
& used.
\end{tabular}

Wan et al. The authors used the MGARCH (2016) model with daily oil price changes as the exogenous variable on Asian stock markets over the period from 1999 to 2014.

Ming, Shen, The authors used the wavelet Yang, Zhu, approach and gathered data and Zhu on spot gold prices from the (2019) Shanghai Composite Index from 1991 to 2016.

\section{Findings}

Gold can be used as an investment asset for the Malaysian emerging equity market. Gold maintains its low positive relation with stock market variations regardless of the market conditions. Gold tends to possess a hedging property in times of equity turbulence.

Gold earned the highest hedging effectiveness on both the Indonesian and Malaysian equities. Hedged portfolio has a lower Sharpe ratio than an unhedged portfolio.
This research extends Ibrahim (2012)'s study by investigating the dynamic nature of gold and equity. Our finding seems to support the initiative by the Malaysian Government to introduce various gold coins, such as Kijang Emas, Royal Mint Gold Dinar, and Kelantan State Gold Dinar, as alternative assets to preserve wealth in the state of financial turbulence.

Our study partially supports Robiyanto et al. (2017) since only the oil-hedged ratio has a lower Sharpe ratio than the unhedged portfolio. The difference could be due to our study's use of weekly instead of monthly data. Further, our study also calculates performance analysis based on the skewness of the return distribution, which found that maximum drawdown reveals that gold-hedged strategy is marginally better than the put replication strategy in Malaysia during the crisis period

This research supports and extends Wan et al. (2016) with DCC-GARCH and several portfolio measurements, and has found that there is a low correlation between oil and equity in ASEAN-5. This study also found that the all-equity stock portfolio in Singapore offers better performance than other strategies since the its capital market is the most advanced Hong Kong, South Korea, and stock market in Southeast Asia. Singapore are recommended as hedges for stock investing especially during negative oil shocks.

Gold is not a hedging instrument for equity in the short term period in China, the UK, and the US. However, after 2005, gold became a hedging instrument in the long run in China, but not in the UK and the US.

The dynamic correlations were positive and low between oil and equities, as well as between oil and gold. The dynamic correlations between GCC stocks and gold were negative and low during the financial crisis, and oil and gold were cheap hedges during
This research partially supports the findings of Ming et al. (2019) since gold is a safe haven in Malaysia and hedging instruments in other ASEAN-5 countries. The authors argue that marketization and trading rules in China are different from those of ASEAN-5 nations, especially Malaysia.

This research partially supports the findings of Maghyereh et al. (2017) in the following ways. Firstly, there is a negative and low correlation between gold and equities in the financial crisis period except

for Indonesia and Thailand. Secondly, we also found that 
Table 7 Selected Recent Studies' Findings Versus This Research's Findings (Continued)

\begin{tabular}{|c|c|c|c|}
\hline & & normal periods. & gold hedge is cheaper than oil. \\
\hline $\begin{array}{l}\text { Mensi } \\
\text { (2019) }\end{array}$ & $\begin{array}{l}\text { The authors used the wavelet } \\
\text { method, Value at Risk } \\
\text { measurement, and daily } \\
\text { closing spot price data for the } \\
\text { Tadawul All Share Index (TASI) } \\
\text { as well as their corresponding } \\
15 \text { sectors. }\end{array}$ & $\begin{array}{l}\text { The results showed notable co- } \\
\text { movements between crude oil } \\
\text { and equity markets over time } \\
\text { and across frequencies. Further, } \\
\text { these co-movements strength- } \\
\text { ened in the global financial } \\
\text { crisis. }\end{array}$ & $\begin{array}{l}\text { This research partially supports } \\
\text { Mensi (2019). It shows that } \\
\text { only the Philippines has a } \\
\text { better oil-hedged performance } \\
\text { during the crisis period. It } \\
\text { seems that the oil effect on } \\
\text { Philippine stocks is weak. In } \\
\text { other words, the co- } \\
\text { movements of ASEAN-5 stock } \\
\text { markets, except for the } \\
\text { Philippines, have increased } \\
\text { among themselves and in the } \\
\text { same path during the oil } \\
\text { shocks. }\end{array}$ \\
\hline $\begin{array}{l}\text { Pandey } \\
\text { (2018) }\end{array}$ & $\begin{array}{l}\text { The authors used three } \\
\text { multivariate GARCH models } \\
\text { (DCC, CCC, and BEKK) to obtain } \\
\text { oil price shocks and gold price } \\
\text { shocks. Their correlations were } \\
\text { tested on the BRICS equity } \\
\text { markets. }\end{array}$ & $\begin{array}{l}\text { The results showed notable } \\
\text { volatility spillover from both } \\
\text { the crude oil and gold to the } \\
\text { BRICS equity markets. There is } \\
\text { evidence of a low (positive) } \\
\text { correlation between gold/ } \\
\text { crude oil and the equity } \\
\text { markets of India and China, } \\
\text { and thus the use of gold/crude } \\
\text { oil would be limited for these } \\
\text { markets. }\end{array}$ & $\begin{array}{l}\text { This research supports Pandey } \\
\text { (2018) that there is evidence of } \\
\text { a low (positive) correlation } \\
\text { between gold/crude oil and } \\
\text { the ASEAN-5 equity markets' } \\
\text { overall sample period. We also } \\
\text { found that gold hedge is } \\
\text { cheaper than oil. }\end{array}$ \\
\hline $\begin{array}{l}\text { Uzo-Peters, } \\
\text { Laniran, } \\
\text { and } \\
\text { Adenikinju } \\
\text { (2018) }\end{array}$ & $\begin{array}{l}\text { The authors used a VAR model } \\
\text { with the impulse response } \\
\text { function and forecast variance } \\
\text { decomposition error. The data } \\
\text { sources were daily stock price } \\
\text { and oil price from January } \\
2007 \text { to December } 2014 \text {. }\end{array}$ & $\begin{array}{l}\text { The results showed that oil } \\
\text { companies in Nigeria should } \\
\text { take a position in the oil } \\
\text { futures market to diversify their } \\
\text { investment. }\end{array}$ & $\begin{array}{l}\text { This research contradicts Uzo- } \\
\text { Peters et al. (2018) since the } \\
\text { drawdown of the oil-hedged } \\
\text { portfolio is worse than the all- } \\
\text { equity portfolios under all sam- } \\
\text { ple periods. We argue that the } \\
\text { reason for this difference is be- } \\
\text { cause Uzo-Peters et al. (2018) } \\
\text { used oil companies while we } \\
\text { used the stock index. }\end{array}$ \\
\hline
\end{tabular}

Source: Authors' analysis

exporting nations is cheaper than in oil-importing countries. Moreover, from the timevarying hedge ratio (Fig. 3), the negative hedge ratio is only found on the gold-hedged portfolio during a crisis period. For instance, the optimal hedge ratios of gold on equity are $-0.05,-0.05,-0.003$, and -0.212 , suggesting that long position on gold is required for the Malaysian, Philippine, Thailand, and Singaporean Indexes. In other words, every 1 USD investment in the Malaysian index should be accompanied by a long (buy) position of 5 cents gold. However, the positive hedge ratio on gold-equity portfolio is found only on the Indonesian market during the crisis period. In other words, every 1 USD investment in the Indonesian index should be accompanied by a short (sell) position of 8 cents oil futures contract. Based on Fig. 3, the researchers argue that the HE during the crisis period is constrained by a relatively higher cost, especially for an oil hedging strategy.

The results of the study also suggest trading strategies across a different market condition in the form of portfolio weights, such as the dynamic one show in Fig. 4. Using the omega ratio overall sample period as a reference point (Table 5), the put replication strategy is recommended in Indonesia, Thailand, and the Philippines. On average, the composition of the bond is $19 \%$ and the composition of the stock is $81 \%$ for Indonesian investors in the overall sample period. Additionally, the composition of the bond is $18 \%$ and the composition of the stock is $82 \%$ for Thailand. For the Philippines, the 


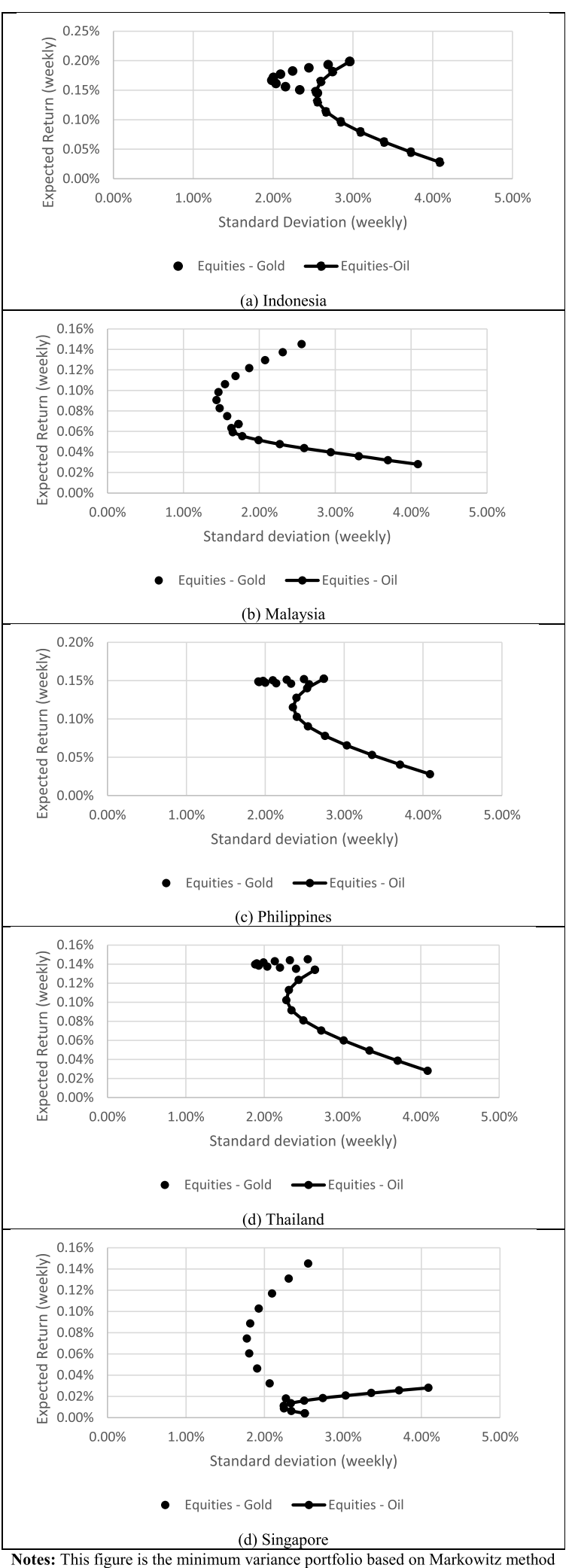

Fig. 5 Minimum Variance Portfolio 
composition of the bond is $17 \%$ and the composition of the stock is $83 \%$. The goldhedged strategy offers better performance in Malaysia, where the composition of gold is $49 \%$ and the composition of the stock is $51 \%$.

When it comes to the crisis period, put replication provides better HE in all countries. However, it does not account for the possible maximum loss of portfolio value. Therefore, using drawdown as a reference point, a gold-hedged strategy is highly recommended in Malaysia whereas the put replication strategy is highly recommended for the rest of the countries during the crisis period. The recommendation of asset allocation during this period is a maximum composition of gold at $70 \%$, which is higher than the maximum composition of gold at $60 \%$ in the normal period, which can be seen in Fig. 4. The comparison of some findings from selected studies with this research can be seen in Table 7 .

Figure 5 shows the robustness results. Consistent with the DCC-GARCH results from all sample periods, the gold-hedging strategy is better than the oil-hedge strategy on equities. The optimum portfolio weight for equity is $42 \%$ of the total weight. In Indonesia, the expected weekly equity-gold portfolio returns and risks in Indonesia are calculated at $0.17 \%$ and $1.98 \%$ respectively. They are $0.11 \%$ and $1.65 \%$ in Malaysia, $0.15 \%$ and $1.91 \%$ in the Philippines, $0.14 \%$ and $1.91 \%$ in Thailand, and $0.09 \%$ and $1.80 \%$ in Singapore. The expected weekly equity-oil portfolio and returns in Indonesia are $0.10 \%$ and $2.80 \%$ respectively, $0.04 \%$ and $2.51 \%$ in Malaysia, $0.08 \%$ and $2.70 \%$ in the Philippines, $0.07 \%$ and $2.67 \%$ in Thailand, and $0.02 \%$ and $2.69 \%$ in Singapore.

Another implication of this study is that risk-averse investors should prefer to put replication or guaranteed financial products compared to commodities-hedged strategy. This result is consistent with Dichtl and Drobetz (2011). Further, portfolio insurance with downside protection can be justified in behavioral finance.

\section{Conclusion}

This study investigates the effectiveness of put replication, gold, and oil for hedging in ASEAN-5 stock indexes from 2007 to 2018. The DCC-GARCH model was used for portfolio construction involving oil, gold, and equities, while protective-put replication is based on the BS formula. The results reveal that the put replication strategy measured by the HE is the best method during crisis, followed by a gold-hedged strategy. However, the maximum drawdown reveals that the gold-hedged strategy is marginally better than the put replication strategy in Malaysia during the crisis period. Overall, gold is a cheaper hedge than oil and oil-hedged strategy is more expensive in nations belonging to the ASEAN-5 compared to those in the Gulf Cooperation Council. In other words, hedging equity using an oil futures contract in oil-importing nations is more expensive than in oilexporting countries. Moreover, investors who have a big exposure to oil should diversify to Philippine equity. Incorporating the Philippine stock index into an oil-related portfolio can bring in diversification opportunities in the short-term period.

From a dynamic correlation perspective, gold has a very low and positive dynamic correlation with equities in ASEAN-5 nations, implying that it is also a risky investment. From the HE perspective, oil is less attractive than money market instruments and gold. Also, gold and oil are not strong safe havens during the financial crisis. Further, the low or negative time-varying correlation, which is used as a reference point to create a portfolio, is consistent with the modern portfolio theory that the creation of a portfolio may reduce volatilities if the returns of the assets have a minimal correlation. 
This research implies that it is advisable to always include money market instruments in the portfolio construction, especially for risk-averse investors. Since gold investment complies with the sharia principle, it is recommended to use it as a hedging strategy compared to the oil futures contract. This study limits the definition of safe haven and the hedging of oil and gold based on specific tails of the distribution, not via quantile-specific distribution. Additionally, the portfolio insurance model is based on the assumption that equity returns are normally distributed according to a Geometric Brownian motion. Therefore, the use of other popular portfolio insurance methods, such as constant proportion portfolio insurance and resetting, is recommended for future research.

\begin{abstract}
Abbreviations
ARCH: Autoregressive Conditional Heteroscedasticity; ASEAN: Association of Southeast Asian Nations; ASEAN5: Indonesia, Malaysia, Singapore, Thailand, and the Philippines; BRICS: Brazil, Russia, India, China, South Africa; CPPI: Constant Proportion Portfolio Insurance; DCC: Dynamic Conditional Correlation; DCC-GARCH: Dynamic Conditional Correlation - Generalized Autoregressive Conditional Heteroscedasticity; ETF: Exchange Traded Funds; GARCH: Generalized Autoregressive Conditional Heteroscedasticity; IDX: Indonesia Stock Exchange; JKSE: Jakarta Composite Index from Indonesia Stock Exchange; KLSE: Kuala Lumpur Stock Exchange; MPH: Modern Portfolio Hypothesis; OBPI: Option-Based Portfolio Insurance; PSEl: Manila Composite Index from Philippines Stock Exchange; SET: Stock Exchange Thailand; STI: Straits Times Index; VIX: Volatility Index; WTI: West Texas Intermediate
\end{abstract}

\title{
Acknowledgments \\ Not Applicable.
}

\section{Authors' contributions}

Robiyanto Robiyanto and Bayu Adi Nugroho conceived the study and were responsible for the design and development of the data analysis. Robiyanto Robiyanto and Bayu Adi Nugroho were responsible for data collection and analysis. Robiyanto Robiyanto and Bayu Adi Nugroho and Eka Handriani were responsible for data interpretation. Robiyanto Robiyanto and Bayu Adi Nugroho and Eka Handriani wrote the first draft. Robiyanto Robiyanto and Bayu Adi Nugroho and Eka Handriani and Andrian Dolfriandra Huruta wrote the revision of the article. The author(s) read and approved the final manuscript.

\section{Funding}

This research received no specific grant from any funding agency in the public, commercial, or not-for-profit sectors.

\section{Availability of data and materials}

The datasets used and/or analyzed during the current study are available from the corresponding author on reasonable request.

Ethics approval and consent to participate

Not Applicable.

\section{Consent for publication}

Not Applicable.

\section{Competing interests}

Authors declare that they have no competing interests.

\section{Author details}

${ }^{1}$ Faculty of Economics and Business, Satya Wacana Christian University, Jl. Diponegoro 52-60, Salatiga 50711, Indonesia.

${ }^{2}$ Faculty of Economics and Business, Perbanas Institute, Jl. Perbanas, South Jakarta 12940, Indonesia. ${ }^{3}$ Faculty of Economics and Business, Darul Ulum Islamic Centre Sudirman University GUPPI, JI. Tentara Pelajar No. 13, Ungaran 50519, Indonesia. ${ }^{4}$ Chung Yuan Christian University, No. 200, Zhongbei Road, Zhongli District, Taoyuan City, Taiwan 320.

Received: 18 November 2019 Accepted: 21 August 2020

Published online: 23 December 2020

\section{References}

Abdullah AM, Saiti B, Masih M (2016) The impact of crude oil price on Islamic stock indices of south east Asian countries: evidence from MGARCH-DCC and wavelet approaches. Borsa Istanbul Rev 16(4):219-232. https://doi.org/10.1016/j.bir. 2015.12.002

Agha SE, Saafi AR, Qayoom OA (2015) Gold investment from Islamic perspective: the case of Malaysia. Int J Econ Financ 7(5): 176-185. https://doi.org/10.5539/ijef.v7n5p179

Arfaoui M, Ben Rejeb A (2017) Oil, gold, US dollar and stock market interdependencies: a global analytical insight. Eur J Manag Bus Econ 26(3):278-293. https://doi.org/10.1108/ejmbe-10-2017-016

Arouri MEH, Lahiani A, Nguyen DK (2014) World gold Proces and stock return in China: insights for hedging and diversification strategies In HAL Working Paper. Retrieved from https://hal.archives-ouvertes.fr/hal-00798038 
Arsyad N (2015) Integration between east and southeast Asian equity markets. J Financial Econ Policy 17(2):104-121. https:// doi.org/10.1108/JFEP-02-2014-0012

Awartani B, Maghyereh Al (2013) Dynamic spillovers between oil and stock markets in the Gulf cooperation council countries. Energy Econ 36:28-42. https://doi.org/10.1016/j.eneco.2012.11.024

Bala DA, Takimoto T (2017) Stock markets volatility spillovers during financial crises: a DCC-MGARCH with skewed- t density approach. Borsa Istanbul Rev 17(1):25-48. https://doi.org/10.1016/j.bir.2017.02.002

Baur DG, Lucey BM (2010) Is gold a hedge or a safe haven? An analysis of stocks, bonds and gold. Financial Rev 45(2):217229. https://doi.org/10.1111/j.1540-6288.2010.00244.x

Baur DG, McDermott TKJ (2012) Safe haven assets and investor behaviour under uncertaintyWorking paper. UTS, School of Business, Finance Discipline Group, Sydney

Baur DG, Tran DT (2012) The long-run relationship of gold and silver and the influence of bubbles and financial crises In Working Paper

Beningga S, Blume M (1985) On the optimality of portfolio insurance. J Financ 40(5):1341-1352. https://doi.org/10.1111/j. 1540-6261.1985.tb02386.x

Boonyasana K (2018) Effect of petroleum product prices on Thailand's economic growth. Int J Econ Policy Emerg Economies 11(1):40-48. https://doi.org/10.1504/IJEPEE.2018.091027

Ciner C, Gurdgiev C, Lucey BM (2013) Hedges and safe havens: an examination of stocks, bonds, gold, oil and exchange rates. Int Rev Financ Anal 29:202-211. https://doi.org/10.1016/j.irfa.2012.12.001

Creti A, Joëts M, Mignon V (2013) On the links between stock and commodity Markets' volatility. Energy Econ 37:16-28. https://doi.org/10.1016/j.eneco.2013.01.005

Dichtl H, Drobetz W (2011) Portfolio insurance and prospect theory investors: popularity and optimal design of capital protected financial products. J Bank Financ 35(7):1683-1697. https://doi.org/10.1016/j.jbankfin.2010.11.012

Engle RF (2002) Dynamic conditional correlation: a simple class of multivariate generalized autoregressive conditional Heteroskedasticity models. J Bus Econ Stat 20(3):339-350. https://doi.org/10.1198/073500102288618487

Filis G, Degiannakis S, Floros C (2011) Dynamic correlation between stock market and oil prices: the case of oil-importing and oil-exporting countries. Int Rev Financ Anal 20(3):152-164. https://doi.org/10.1016/j.irfa.2011.02.014

Ghazali MF, Lean HH, Bahari Z (2015) Sharia compliant gold Investment in Malaysia: hedge or safe haven? Pac Basin Financ J 34:192-204. https://doi.org/10.1016/j.pacfin.2014.12.005

Gusdinar IA, Koesrindartoto DP (2013) Institutional investors trading strategy in Indonesia' s government bond market during the 2008 crisis. Asian Acad Manage J Account Finance 10(1):21-44

Hersugondo S, Robiyanto R, Wahyudi S, Muharam H (2015) The world oil Price movements and stock returns in several Southeast Asia's capital markets. Int J Appl Bus Econ Res 13(2):527-534

Hoang THV, Lahiani A, Heller D (2016) Is gold a hedge against inflation? New evidence from a nonlinear ARDL approach. Econ Model 54:54-66. https://doi.org/10.1016/j.econmod.2015.12.013

Hood M, Malik F (2013) Is gold the best hedge and a safe haven under changing stock market volatility. Rev Financial Econ 22(2):47-52. https://doi.org/10.1016/j.rfe.2013.03.001

Ibrahim MH (2012) Financial risk market and gold Investment in an Emerging Market: the case of Malaysia. Int J Islamic Middle Eastern Finance Manage Res News 5(1):25-34. https://doi.org/10.1108/17538391211216802

Iglesias-Casal A, López-Penabad M-C, López-Andión C, Maside-Sanfiz JM (2020) Diversification and optimal hedges for socially responsible investment in Brazil. Econ Model 85:106-118. https://doi.org/10.1016/j.econmod.2019.05.010

Jarungkitkul W, Sukcharoensin S (2016) Benchmarking the competitiveness of the ASEAN 5 equity markets. BIJ 23(5):13121340. https://doi.org/10.1108/bij-05-2014-0047

Jung YC (2016) A portfolio insurance strategy for volatility index (VIX) futures. Q Rev Econ Finance 60:189-200. https://doi. org/10.1016/j.qref.2015.09.001

Karim BA, Ning HX (2013) Driving forces of the ASEAN-5 stock markets integration. Asia-Pacific J Bus Admin 5(3):186-191. https://doi.org/10.1108/APJBA-07-2012-0053

Kroner KF, Sultan J (1993) Time-varying distributions and dynamic hedging with foreign currency futures. J Financ Quant Anal 28(4):535-551

Kroner KF, Ng VK (1998). Modelling Asymmetric Comovements of Assets Returns. Review of Financial Studies, 11(4), 817-844.

Le T-H, Chang Y (2012) Oil Price shocks and gold returns. Int Econ 131:71-104

Liquidity in the Global Gold Market. (2011). Retrieved from https://www.gold.org/download/file/7760/liquidity_in_the_global_ gold_market.pdf

Lucey BM, O'Connor FA (2013) Do bubbles occur in the gold Price? An investigation of gold lease rates and Markov switching models. Borsa Istanbul Rev 13(3):53-63. https://doi.org/10.1016/j.bir.2013.10.008

Maghyereh Al, Awartani B, Tziogkidis P (2017) Volatility spillovers and cross-hedging between gold, oil and equities: evidence from the Gulf cooperation council countries. Energy Econ 68:440-453. https://doi.org/10.1016/j.eneco.2017.10.025

Markowitz HM (1952) Portfolio selection. J Financ 7(1):77-91. https://doi.org/10.1111/j.1540-6261.1952.tb01525.x

Mensi W (2019) Global financial crisis and co-movements between oil prices and sector stock markets in Saudi Arabia: a VaR based wavelet. Borsa Istanbul Rev 19(1):24-38. https://doi.org/10.1016/j.bir.2017.11.005

Ming L, Shen Y, Yang S, Zhu S, Zhu H (2019) Does gold serve as a hedge for the stock market in China? Evidence from a time-frequency analysis. Emerg Mark Financ Trade 56(3):659-672. https://doi.org/10.1080/1540496X.2019.1677225

Ming L, Zhang X, Liu Q, Yang S (2020) A revisit to the hedge and safe haven properties of gold: new evidence from China. J Futur Mark. https://doi.org/10.1002/fut.22124

Muharam H, Robiyanto R, Pangestuti IRD, Mawardi W (2020) Measuring Asian stock market integration by using orthogonal generalized autoregressive conditional heteroscedasticity. Montenegrin J Econ 16(1):121-137. https://doi.org/10.14254/ 1800-5845/2020.16-1.8

Nugroho BA, Juwono E, Wijayanti I (2018) Do leading macroeconomic factors impact on optimal portfolio return in Indonesia? Binus Business Rev 9(1):19-27. https://doi.org/10.21512/bbr.v9i1.3960

Pandey V (2018) Volatility spillover from crude oil and gold to BRICS equity markets. J Econ Stud 45(2):426-440. https://doi. org/10.1108/jes-01-2017-0025

Perold AF, Sharpe WF (1988) Dynamic strategies for asset allocation. Financ Anal J 44(1):16-27 
Putra MPS, Atahau ADR, Robiyanto R (2018) Cross-asset class portfolio between gold and stocks in Indonesia. Econ J Emerg Markets 10(1):69-81. https://doi.org/10.20885/ejem.vol10.iss1.art8

Robiyanto R (2018a) The dynamic correlation between ASEAN-5 stock markets and world oil prices. J Keuangan dan Perbankan 22(2):198-210. https://doi.org/10.26905/jkdp.v22i2.1688

Robiyanto R (2018b) Gold VS bond: what is the safe haven for the Indonesian and Malaysian capital market? Gadjah Mada Int J Business 20(3):277-302. https://doi.org/10.22146/gamaiib.27775

Robiyanto R, Ernayani R, Ismail RS (2019a) Formulation of a dynamic portfolio with stocks and fixed-income instruments in the Indonesian capital market. Organ Mark Emerg Econ 10(1):132-146. https://doi.org/10.15388/omee.2019.10.00007

Robiyanto R, Hadiyatno D, Sudjinan S, Ernayani R (2019b) Gold and capital market in Indonesia: a preview on strategy of hedging and diversification. J Int Stud 12(2):117-128. https://doi.org/10.14254/2071-8330.2019/12-2/7

Robiyanto R, Wahyudi S, Pangestuti IRD (2017) The volatility-variability hypotheses testing and hedging effectiveness of precious metals for the Indonesian and Malaysian capital markets. Gadjah Mada Int J Business 19(2):167-192. https://doi. org/10.22146/gamaiib.26260

Rubinstein M, Leland HE (1995) Replicating options with positions in stock and cash. Financ Anal J 51(1):113-121

Shahzad SJH, Bouri E, Roubaud D, Kristoufek L, Lucey B (2019) Is bitcoin a better safe-haven investment than gold and commodities? Int Rev Financ Anal 63:322-330. https://doi.org/10.1016/j.irfa.2019.01.002

Shakil MH, Mustapha IHM, Tasnia M, Saiti B (2018) Is gold a hedge or a safe haven? An application of ARDL approach. J Econ Finance Admin Sci 23(44):60-76. https://doi.org/10.1108/jefas-03-2017-0052

Singh NP, Joshi N (2019) Investigating gold investment as an inflationary hedge. Bus Perspect Res 7(1):30-41. https://doi.org/ $10.1177 / 2278533718800178$

Soyemi KA, Akingunola RO-O, Ogebe J (2017) Effects of oil price shock on stock returns of energy firms in Nigeria. Kasetsart J Soc Sci. https://doi.org/10.1016/j.kjss.2017.09.004

Thomas NM, Kashiramka S, Yadav SS (2017) Dynamic linkages among developed, emerging and frontier capital markets of Asia-Pacific region. J Adv Manage Res 14(3):332-351. https://doi.org/10.1108/jamr-10-2016-0088

Trabelsi N (2017) Tail dependence between oil and stocks of major oil-exporting countries using the CoVaR approach. Borsa Istanbul Rev 17(4):228-237. https://doi.org/10.1016/j.bir.2017.07.001

Uzo-Peters A, Laniran T, Adenikinju A (2018). Brent prices and oil stock behaviors: evidence from Nigerian listed oil stocks. Financial Innovation, 4(1). https://doi.org/10.1186/s40854-018-0092-2

Vo DH, Pham TN, Pham TTV, Truong LM, Cong Nguyen T (2019) Risk, return and portfolio optimization for various industries in the ASEAN region. Borsa Istanbul Rev 19(2):132-138. https://doi.org/10.1016/j.bir.2018.09.003

Wan J-T, Lau E, Brahmana RK (2016) Contagious effects of oil prices on Asian stock markets' behaviour. J Indonesian Econ Business 31(2):141-162. https://doi.org/10.22146/jieb.15275

Wen F, Xu L, Ouyang G, Kou G (2019) Retail investor attention and stock price crash risk: evidence from China. Int Rev Financ Anal 65. https://doi.org/10.1016/j.irfa.2019.101376

Zhao W, Asali M, Karbhari Y, Lau W-T (2018) Stock market linkage and impact of the sub-prime mortgage crisis: evidence from mainland China and Hong Kong. Int J Econ Manage 12(S2):619-631

Zhu Y, Dickinson D, Li J (2017) Analysis on the influence factors of Bitcoin's price based on VEC model. Financial Innov 3(1). https://doi.org/10.1186/s40854-017-0054-0

\section{Publisher's Note}

Springer Nature remains neutral with regard to jurisdictional claims in published maps and institutional affiliations.

\section{Submit your manuscript to a SpringerOpen ${ }^{\circ}$ journal and benefit from:}

- Convenient online submission

- Rigorous peer review

- Open access: articles freely available online

- High visibility within the field

- Retaining the copyright to your article

Submit your next manuscript at $\boldsymbol{\nabla}$ springeropen.com 